Roberto Luis Hollmann

\title{
A Systematic Literature Review of Collaborative Planning Forecasting and Replenishment
}

Dissertação de Mestrado (Opção profissional)

Thesis presented to the Programa de PósGraduação em Engenharia de Produção of the Departamento de Engenharia Industrial, PUC-Rio, as partial fulfillment of the requirements for the degree of Mestre em Engenharia de Produção - opção profissional.

Advisor: Prof. Dr. Luiz Felipe Roris Rodriguez Scavarda do Carmo

Co-advisor: Dr. Antônio Márcio Tavares Thomé 


\title{
Pontifícia Universidade Católica
}

do Rio de Janeiro

Roberto Luis Hollmann

\section{A Systematic Literature Review of Collaborative Planning Forecasting and Replenishment}

\begin{abstract}
Thesis presented to the Programa de Pós-Graduação em Engenharia de Produção of the Departamento de Engenharia Industrial, PUC-Rio, as partial fulfillment of the requirements for the degree of Mestre em Engenharia de Produção - opção profissional.
\end{abstract}

Prof. Luiz Felipe Roris Rodriguez Scavarda do Carmo

Advisor

Departamento de Engenharia Industrial - PUC-Rio

Dr. Antônio Márcio Tavares Thomé

Co-advisor

BEMFAM

Prof $^{\mathrm{a}}$. Adriana Leiras

Departamento de Engenharia Industrial - PUC-Rio

Prof. Fernando Luiz Cyrino Oliveira

Departamento de Engenharia Industrial - PUC-Rio

Prof. José Eugênio Leal

Coordenador(a) Setorial do Centro Técnico Científico - PUC-Rio

Rio de Janeiro, April 11th, 2014. 
All rights reserved.

\section{Roberto Luis Hollmann}

Roberto Luis Hollmann graduated in Industrial Engineer at Centro Universitário - UNIVATES in 2009. He worked during six years at BRF - Brasil Foods with production planning and control and sales and operations planning (S\&OP). Since 2011 he works at Petrobras Exploration division.

Bibliographic data

Hollmann, Roberto Luis

A Systematic Literature Review of Collaborative Planning Forecasting and Replenishment / Roberto Luis Hollmann; orientador: Luiz Felipe Roris Rodriguez Scavarda do Carmo. co-orientador: Antônio Márcio Tavares Thomé. - 2014.

74 f. : il. ; $30 \mathrm{~cm}$

Dissertação (Mestrado em Engenharia Industrial) Pontifícia Universidade Católica do Rio de Janeiro, Rio de Janeiro, 2014.

Inclui bibliografia

1. Engenharia industrial - Teses. 2. CPFR. 3. Revisão da literatura. 4. Pesquisa em contingência. 5. Colaboração na cadeia de suprimentos. 6. Gestão de operações. I. Carmo, Luiz Felipe Roris Rodriguez Scavarda. II. Pontifícia Universidade Católica do Rio de Janeiro. Departamento de Engenharia Industrial. III. Título. 
To my wife. 


\section{Acknowledgments}

First of all, I want to thank my advisor Prof. Luiz Felipe Scavarda for believing in me to develop this work. I would like to express my gratitude to him and to my co-advisor Márcio Thomé for their ideas, commitment and valuable time to support me in this work. Without their guidance and persistent help this dissertation would not have been possible.

I acknowledge the professors who kindly accepted the invitations to collaborate with their experience for the evaluation of this study.

I am grateful to PUC's professors, staff and my colleagues who shared their time and knowledge with me.

I would like to acknowledge my company, Petrobras, which invest on employee's education/qualification. Many thanks to Polônia, Ubirajara and Pedro for their support, and to Carlos and Livia for bearing my share of work when I needed to leave early to study.

Furthermore I would like to thank my wife Estefane for her encouragement, support, advice, and understanding.

Last but not least, I am very grateful to my family, for all that they represent in my life. Especially to my mother and father who taught how valuable education is. 


\section{Abstract}

Hollmann, Roberto Luis; Carmo, Luiz Felipe Roris Rodriguez Scavarda; Thomé, Antônio Márcio Tavares. A Systematic Review of Collaborative Planning Forecasting and Replenishment. Rio de Janeiro, 2014. 65p. Dissertação de Mestrado (Opção profissional) - Departamento de Engenharia Industrial, Pontifícia Universidade Católica do Rio de Janeiro.

Collaborative Planning, Forecasting and Replenishment (CPFR) is considered by many researches to be the most advanced and the most comprehensive Supply Chain Collaboration (SCC) initiative. Despite its relevance and growing number of publications, efforts to synthesise the overall state of the art in CPFR have been rather limited to date. As an effort to fill this gap, this dissertation aims to go beyond the highly dispersed work on CPFR by providing a systematic review of the literature and the key findings on the topic. The dissertation analyses CPFR models, discusses main enablers and barriers for implementation and CPFR and other SCC impact on Supply Chain (SC) performance. A framework is also proposed as an aide to assemble and organise the literature review. The structure of the framework embraces all the constitutive elements required to describe individual CPFR elements (context, inputs, structure and processes, outcomes and results), their relationships and impact upon firm performance. The framework also shows the vertical functional role of CPFR in bridging business and corporate strategic plans from SC members to joint SC operations. This dissertation contributes to a better understanding of the field and provides directions for future research and practice in CPFR and SCC.

\section{Keywords}

CPFR, literature review, contingency research, supply chain collaboration, operations management. 


\section{Resumo}

Hollmann, Roberto Luis; Carmo, Luiz Felipe Roris Rodriguez Scavarda; Thomé, Antônio Márcio Tavares. Uma revisão sistemática da literatura em Planejamento, Previsão e Reabastecimento Colaborativo. Rio de Janeiro, 2014. 65p. Dissertação de Mestrado (Opção profissional) - Departamento de Engenharia Industrial, Pontifícia Universidade Católica do Rio de Janeiro.

Colaboração na cadeia de suprimentos (SCC) é um tema que tem sido amplamente discutido na literatura e é aceito que a criação de uma cadeia de suprimentos sincronizada leva ao aumento da capacidade de resposta e a menores custos de estoque. O Planejamento, Previsão e Reabastecimento Colaborativo (CPFR) é considerado por muitos autores como a mais avançada e abrangente iniciativa em SCC. Apesar do crescente número de publicações sobre CPFR, a literatura acadêmica revela a ausência de uma pesquisa que sintetize o estado da arte sobre CPFR. Desta forma, esta dissertação tem como objetivo, por meio da revisão sistemática da literatura, reunir e integrar o conhecimento sobre CPFR como um processo de negócio e como uma prática de gestão. Foram analisados 629 resumos e 47 artigos foram selecionados para a revisão e classificação. A dissertação analisa os modelos de CPFR, apresenta os principais facilitadores e barreiras para a implementação do CPFR e as diferenças entre CPFR e outras iniciativas de SCC e seus impactos no desempenho da cadeia de suprimentos (SC). Um modelo conceitual (framework) é proposto para guiar e organizar a revisão da literatura. A estrutura do framework abrange todos os elementos constitutivos necessários para descrever os elementos individuais do CPFR (contexto, insumos, estrutura e processos e resultados), suas relações e o impacto sobre o desempenho da empresa. $O$ framework também mostra o papel funcional vertical do CPFR em construir uma ponte entre os negócios e planos estratégicos corporativos dos membros da SC com as operações conjuntas na SC. Apesar de existirem vários modelos para o CPFR, não há um consenso sobre as diferentes configurações para o CPFR. Estas diferenças são atribuídas ao estágio 
de desenvolvimento em modelos de maturidade, a diferentes contextos e estratégias de implementação, de acordo com a pesquisa da contingência em gestão de operações, e a singularidade dos recursos e dependências entre as empresas na cadeia de suprimentos, conforme a visão baseada em recursos e a visão baseada na dependência. A responsividade aparece como o principal objetivo na implementação do CPFR e o custobenefício do CPFR deve ser comparado com os de outras iniciativas de SCC para a escolha da mais adequada à cadeia de suprimentos. Apenas três estudos confirmatórios relatam o impacto do CPFR na cadeia de suprimentos. Esta dissertação contribui para uma melhor compreensão do tema e fornece indicações para futuras pesquisas e práticas em CPFR e SCC.

\section{Palavras-chave}

CPFR, revisão da literatura, pesquisa em contingência, colaboração na cadeia de suprimentos, gestão de operações. 


\section{Contents}

1 Introduction 15

2 Methodology and study identification $\quad 18$

$\begin{array}{lr}\text { 2.1. Methodology } & 18\end{array}$

2.2. Study identification $\quad 20$

3 Basics of CPFR 24

3.1. Defining CPFR 24

3.1.1. A definition for CPFR 25

3.2. Implementing CPFR 26

3.3. CPFR models 28

3.4. CPFR vs. other SCC initiatives 36

4 Results and discussions $\quad 41$

4.1. A literature search synthesis framework 41

4.2. Study descriptors 44

4.2.1. Business and corporate strategic plans 44

4.2.2. Context 45

4.2.3. Inputs 47

4.2.4. Structure and processes 51

4.2.5. Outcomes and results $\quad 57$

$\begin{array}{ll}5 \text { Conclusions and future research } & 61\end{array}$

$\begin{array}{ll}\text { References } & 66\end{array}$

Appendix I - Classification of inputs to the CPFR process 72

$\begin{array}{ll}\text { Appendix II - CPFR metrics } & 73\end{array}$

Appendix III - Results of the CPFR process $\quad 74$ 


\section{List of figures}

Figure 1 - VICS first model 31

Figure 2 - VICS second model $\quad 35$

Figure 3 - Literature search synthesis framework 43 


\section{List of tables}

Table 1 - Results of the process to retrieve studies 19

Table 2 - Publications, number of citations, source and methodology 20

Table 3 - CPFR models $\quad 30$

Table 4 - Studies comparing different SCC initiatives 39

Table 5 - Classification of inputs to the CPFR process 49

Table 6 - CPFR metrics $\quad 56$

Table 7 - Results of the CPFR process 58 


\section{List of acronyms}

A-CPFR - augmented Collaborative Planning, Forecasting and Replenishment

AR - Accurate Response

ASP - Application Service Provider

ATO - Assemble-to-Order

AVE - Agile Value Enterprise

BPMJ - Business Process Management Journal

CFAR - Collaborative Forecasting and Replenishment

$\mathrm{Cl}$ - Computers in Industry

CIM - Centralised Inventory Management

CPFR - Collaborative Planning, Forecasting and Replenishment

CR - Continuous Replenishment

CRP - continuous replenishment policy

CTM - Collaborative Transportation Management

DMAIC - Define, Measure, Analyse, Improve and Control

ECR - Efficient Consumer Response Movement

EDI - Electronic Data Interchange

ESA - Expert Systems with Applications

GS - Google Scholar

I\&M - Information \& Management

IBP - integrated business planning

ICT - Information and Communication Technology

IJAMT - International Journal of Advanced Manufacturing Technology

IJCIM - International Journal of Computer Integrated Manufacturing

IJITDM - International Journal of Information Technology \& Decision

Making

IJLM - International Journal of Logistics Management, The

IJOPM - International Journal of Operations \& Production Management

IJPDLM - International Journal of Physical Distribution \& Logistics Management 
IJPE - International Journal of Production Economics

IJPR - International Journal of Production Research

IM - Industrial Management

IMDS - Industrial Management \& Data Systems

JAIS - Journal of the Association for Information Systems

JBF - Journal of Business Forecasting

JEIM - Journal of Enterprise Information Management

JMI - Joint Managed Inventory

JMTM - Journal of Manufacturing Technology Management

JMTP - Journal of Marketing Theory \& Practice

JOM - Journal of Operations Management

JPSM - Journal of Purchasing and Supply Management

MAPE - Mean Absolute Percentage Error

MTO - Make-to-Order

MTS - Make-to-Stock

OM - Operations Management

POS - Point of Sales

$\mathrm{QR}$ - quick response

RBV - Resource-based View

RCIM - Robotics and Computer-Integrated Manufacturing

RDT - Resource Dependent Theory

RR - Rapid Replenishment

S\&OP - Sales and Operations Planning

SC - Supply Chain

SCC - Supply Chain Collaboration

SCFIJ-Supply Chain Forum: an International Journal

SCMIJ - Supply Chain Management: An International Journal

SCR - Synchronised Consumer Response

SKU - Stock Keeping Unit

TJ - Transportation Journal

USA - United States of America

VICS - Voluntary Inter-industry Commerce Standard

VMI - Vendor Managed Inventory 
WASET - World Academy of Science, Engineering \& Technology 


\section{Introduction}

Supply chain collaboration (SCC) has been extensively discussed in the literature, and it is widely accepted that creating a seamless, synchronised supply chain (SC) leads to increased responsiveness and lower inventory costs (Holweg et al., 2005). As SCC has become vitally important for achieving competitive advantage (Kumar and Banerjee, 2012), top management's interest in the subject has grown in the last decades (Danese, 2011). Simatupang and Sridharan (2002) describe SCC as two or more companies working together to create a competitive advantage and higher profits than can be achieved by acting alone. SCC is a process that promotes inter-organisational co-operation, joint work, openness, inter-company decision making, information and knowledge sharing and customer-supplier intimacy (Danese, 2011).

Since the mid-1990s, a large number of SCC initiatives have been developed to improve SC performance and have been discussed in the literature (Holweg et al., 2005, Kumar and Banerjee, 2012, Ramanathan, 2014). Among these initiatives, Collaborative Planning, Forecasting and Replenishment (CPFR) is considered by many researchers to be the most advanced and the most comprehensive (Barrat and Oliveira, 2001, Seifert, 2003, Attaran and Attaran, 2007, Du et al., 2009, VICS, 2010, Danese, 2011).

CPFR is a collaboration process whereby SC trading partners activate interfirm coordination mechanisms to jointly plan key SC activities, from production and delivery of raw materials to production and delivery of final products to end customers (Danese et al., 2004). CPFR intends to improve jointly managed planning processes and shared information among SC partners (Seifert, 2003), bridging supply and demand (Stank et al., 1999; Simatupang and Sridharan, 2005; Sari, 2008b). It is also a cohesive bundle of business practices combining the collaborative intelligence of multiple trading partners in the planning and fulfillment of customer demand, according to a pre specified framework (VICS, 2010). 
As CPFR processes mature, they embrace different levels of integration (e.g. the degree of discussion, data exchanged, plan synchronisation) or different business processes, from basic to developing and advanced stages (Larsen et al., 2003). From a contingency view, CPFR takes different forms, according to the industry sector, product characteristics, depth and scope of the collaboration, trust among partners, spatial complexity/distance between participating firms, goals of the collaboration, number of steps taken to achieve collaboration, and number of partners involved (ECR Europe, 2001, 2002; Larsen et al., 2003; Seifert, 2003; Danese,2006b, 2011). For the resource-based view (RBV) and resource dependent theory (RDT) of the firm, companies engage in CPFR processes with inimitable and unique resources to gain competitive advantages (Ramanathan and Gunasekaran, 2014).

CPFR was developed by the practitioners in the mid-1990s (Poler et al., 2008) as Collaborative Forecasting and Replenishment (CFAR) but was later renamed CPFR to emphasise the role of planning (Seifert, 2003; Burnette, 2010). Originally built as an inter-industry standard, it was designed to move beyond the shortcomings of Electronic Data Interchange (EDI) protocols and the Efficient Consumer Response Movement (ECR), incorporating most of the techniques used to integrate SC partners under the initiatives of Vendor Managed Inventory (VMI) and Continuous Replenishment (CR) (Stank et al., 1999, Barratt and Oliveira, 2001, Larsen et al., 2003, Seifert, 2003, Fliedner, 2003, Attaran, 2004, Cassivi, 2006, Thron et al., 2006, Attaran and Attaran, 2007, Danese, 2007, 2011). The first CPFR pilot project was conducted by Wall-Mart and Warner-Lambert with the goal of being highly responsive to customer demand (Sherman, 1998, Barratt and Oliveira, 2001, Fliedner, 2003, Larsen et al., 2003, Attaran, 2004, Danese, 2006b, Poler et al., 2008, Derrouiche et al., 2008, Burnette, 2010, Lapide, 2010, Ramanathan and Gunasekaran, 2014). CPFR has a broad focus that includes promotions, point of sales (POS) data and order forecast plans that are synchronised among partners in the SC, through joint decisions and exception management (Danese, 2011). A sustained attention is being given to CPFR initiatives due to the "success stories" reported from leading focal companies such as Wall Mart and Nabisco, among several others (Barratt and Oliveira, 2001, Danese, 2006b, Attaran and Attaran, 2007, Danese, 2011). By 2010, the Voluntary Inter-industry Commerce Standard (VICS) committee reported that 
over 300 companies had implemented CPFR initiatives (Lapide, 2010, Yao et al., 2013).

In 1998, the VICS committee published the first working paper with best practices and a guideline for implementation, reviewed later in 2004 and 2010 (VICS, 1998, 2004, 2010, Barratt and Oliveira, 2001, Larsen et al., 2003, Danese, 2007, 2011, Chang and Wang, 2008, Poler et al., 2008, Du et al., 2009, Baumann, 2010, Smith et al., 2010). The first academic papers specifically examinig the subject date from the end of last century. Within the last 15 years, however, the body of literature on CPFR has grown significantly. Despite this growth, efforts to synthesise the overall state of the art of research in this area have been rather limited.

As an effort to fill this gap in the literature, this dissertation aims to go beyond the highly dispersed work on CPFR by providing a systematic review of the literature and the key findings on the topic. The CPFR review is organised by, basics of CPFR and results and discussion with a literature synthesis framework. This study reviews 629 abstracts, 53 full-text papers and retrieves 47 studies for analysis and classification.

The dissertation is divided in five chapters, being this first one the introduction. The second Chapter presents the methodology and the study identification. Chapter three refers to basics of CPFR with key definitions, implementation requirements, main available models and differences with others SCC initiatives. Chapter four presents a framework to assemble and organise the literature review as well as results and discussions organised within this framework. Finally, the main conclusions and suggestions for future research are presented in Chapter five. 


\section{2 Methodology and study identification}

This chapter presents first the methodology and next the study identification.

\section{1. \\ Methodology}

The dissertation is a systematic literature review on CPFR. Systematic literature reviews are a mean of providing an objective theoretical evaluation of a particular topic (Hopayian, 2001). As such, this type of review facilitates the identification, evaluation, and interpretation of studies in a given area by first examining existing concepts, practices, and theories and subsequently summarising the state of the reproducible research in a specific area (Rowley and Slack, 2004, Seuring and Müller, 2008). Literature reviews facilitate a better understanding of the issues associated with a topic of research (Burgess et al., 2006) and provide guidance for future studies to address existing knowledge gaps.

The selection and retrieval of papers in the systematic review conducted in this dissertation is a six-step process adapted from Thomé et al. (2012a, 2012b): (i) computerised database selection, (ii) identification of keywords for search, (iii) criteria for the exclusion of studies, (iv) manual review of selected abstracts, (v) full-text review, and (vi) review of selected references from articles retrieved in step (v).

Four databases that contain papers published in the large majority of scientific journals pertaining to operations, organisational management, and social sciences research were selected for the search: Emerald, EBSCO, ScienceDirect and Wiley. A grey literature review was included in the search databases and manual searches. Scientific grey literature consists of newsletters, reports, working papers, thesis, government documents, bulletins, fact sheets, conference proceedings and other publications that are distributed freely, available by subscription or available for purchase (Weintraub, 2000). The grey literature 
allows the inclusion of bibliographic sources that extends beyond peer-reviewed academic journals and that are likely to not be selected otherwise (Thomé et al., 2012a). In accordance with recommendations for an initial research synthesis (Cooper, 2010), the keywords selected were sufficiently broad to avoid artificially limiting results while still providing limitations to avoid undesirable results. In pseudo code, the following phrase was adapted to the search engines of each database: Collaborative Planning, Forecasting and Replenishment AND CPFR with no limitations regarding publication dates.

The search returned 629 papers. Following Cooper (2010), threats to validity were regrouped in broad categories and used as criteria for the exclusion of papers. The author adopted six exclusion criteria: (i) lack of relevance or poorly defined constructs of CPFR, (ii) CPFR incorporated as an example, rather than as a research topic, (iii) papers treating CPFR elements in isolation of each other, such as inventory management, replenishment or demand forecast, (iv) papers' based only on authors' opinions and/or anecdotal evidence, (v) papers from trade and industry magazines, (vi) papers showing causal relationships that did not present clearly defined empirical evidence based on explicit mathematical modelling, simulations, survey research or case studies.

Based on the reading of abstracts, duplicate papers and papers that did not correspond to the selection criteria were excluded, resulting in 53 papers selected for full-text review. After the full-text reading, an additional six papers were excluded. References added as a result of step (vi) (VICS, 1998, ECR Europe, 2001, ECR Europe, 2002, Seifert, 2003, VICS, 2004, VICS, 2010), retrieval of selected references were used during the analysis and for refining the literature search framework but were not included in Table 2 (see section 2.2), which report only those papers selected during abstract and full text review. This six-step process resulted in 47 papers and six additional references as depicted in Table 1.

Table 1 - Results of the process to retrieve studies

\begin{tabular}{|c|c|c|c|c|c|c|}
\hline Database & Step1 & Step2 & Step3 & Step4 & Step5 & Step6 \\
\hline EBSCO & & & 198 & 20 & 17 & 17 \\
\hline Emerald & & & 186 & 19 & 18 & 18 \\
\hline ScienceDirect & & & 198 & 13 & 11 & 11 \\
\hline Wiley & & & 47 & 1 & 1 & 1 \\
\hline $\begin{array}{l}\text { Others (VICS, 1998, ECR Europe, 2001, } \\
\text { ECR Europe, 2002, Seifert, 2003, VICS, } \\
\text { 2004, VICS, 2010) }\end{array}$ & & & & & & 6 \\
\hline Total & & & 629 & 53 & 47 & 53 \\
\hline
\end{tabular}




\section{2.}

\section{Study identification}

The 47 articles included in the analysis are listed in Table 2 together with the number of citations, source and methodology.

Table 2 - Publications, number of citations, source and methodology

\begin{tabular}{|c|c|c|c|}
\hline Reference & \# of citations & Source & Methodology \\
\hline $\begin{array}{l}\text { Sherman (1998) } \\
\text { (19) }\end{array}$ & 55 & JMTP & Conceptual model \\
\hline Stank et al. (1999) & 145 & SCMIJ & Survey \\
\hline Barratt and Oliveira (2001) & 327 & IJPDLM & Survey \\
\hline Holmström et al. (2002) & 124 & SCMIJ & Conceptual model \\
\hline McCarthy and Goilicic (2002) & 155 & IJPDLM & Case study, multiple \\
\hline Esper and Williams (2003) & 116 & $\mathrm{TJ}$ & Conceptual model \\
\hline Fliedner (2003) & 167 & IMDS & Conceptual model \\
\hline Larsen et al.(2003) & 218 & IJPDLM & Survey \\
\hline Attaran (2004) & 20 & $\mathrm{IM}$ & Industry report \\
\hline Danese et al.(2004) & 64 & JPSM & Case study, multiple \\
\hline Caridi et al. (2005) & 54 & IJPR & Simulation \\
\hline Ireland (2005) & 7 & $\mathrm{JBF}$ & Industry report \\
\hline Simatupang and Sridharan (2005) & 137 & IJLM & Conceptual model \\
\hline Caridi et al. (2006) & 20 & JEIM & Simulation \\
\hline Cassivi (2006) & 89 & SCMIJ & Survey \\
\hline Danese (2006a) & 3 & SCFIJ & Conceptual model \\
\hline Danese (2006b) & 46 & IJPR & Case study, multiple \\
\hline Thron et al. (2006) & 18 & IJPDLM & Simulation \\
\hline Attaran and Attaran (2007) & 78 & BPMJ & Conceptual model \\
\hline Chang et al. (2007) & 24 & SCMIJ & Simulation \\
\hline Chen et al.(2007) & 32 & $\mathrm{I} \& \mathrm{M}$ & Simulation \\
\hline Danese (2007) & 70 & IJOPM & Case study, multiple \\
\hline Småros (2007) & 56 & $\mathrm{JOM}$ & Case study, single \\
\hline Thron et al. (2007) & 17 & IJLM & Simulation \\
\hline Chang and Wang (2008) & 14 & IJAMT & Case study, single \\
\hline D'Aubeterre et al. (2008) & 19 & JAIS & Case study, single \\
\hline Derrouiche et al. (2008) & 30 & IJCIM & Conceptual model \\
\hline Ghosh and Fedorowicz (2008) & 46 & BPMJ & Case study, single \\
\hline Poler et al. (2008) & 33 & JMTM & Simulation \\
\hline Sari (2008a) & 21 & IMDS & Simulation \\
\hline Sari (2008b) & 65 & IJPE & Simulation \\
\hline Büyüközkan et al. (2009) & 5 & WASET & Simulation \\
\hline Du et al. (2009) & 19 & SCMIJ & Case study, multiple \\
\hline Baumann (2010) & 3 & JBF & Conceptual model \\
\hline Burnette (2010) & 1 & $\mathrm{JBF}$ & Industry report \\
\hline Choi and Sethi (2010) & 45 & IJPE & Literature review \\
\hline Hvolby andTrienekens (2010) & 23 & $\mathrm{CI}$ & Conceptual model \\
\hline
\end{tabular}


Table 2 - Publications, number of citations, source and methodology

\begin{tabular}{lccl}
\hline Reference & \# of citations & Source & Methodology \\
\hline Lapide (2010) & 1 & JBF & Industry report \\
Shu et al. (2010) & 0 & IJITDM & Conceptual model \\
Smith et al. (2010) & 6 & JBF & Industry report \\
Yuan et al. (2010) & 7 & RCIM & Case study, single \\
Danese (2011) & 15 & IJPR & Case study, multiple \\
Büyüközkan andVardaloğlu (2012) & 9 & ESA & Simulation \\
Audy et al. (2012) & 19 & ITOR & Case study, multiple \\
Yao et al. (2013) & 0 & JOM & Case study, single \\
Ramanathan (2014) & 1 & ESA & Simulation \\
Ramanathan and Gunasekaran (2014) & 9 & IJPE & Survey \\
\hline
\end{tabular}

BPMJ - Business Process Management Journal; CI - Computers in Industry; ESA - Expert Systems with Applications; I\&M - Information \& Management; IJAMT - International Journal of Advanced Manufacturing Technology; IJCIM - International Journal of Computer Integrated Manufacturing; IJITDM - International Journal of Information Technology \& Decision Making; IJLM International Journal of Logistics Management, The; IJOPM - International Journal of Operations \& Production Management; IJPDLM - International Journal of Physical Distribution \& Logistics Management; IJPE - International Journal of Production Economics; IJPR - International Journal of Production Research; IM - Industrial Management; IMDS - Industrial Management \& Data Systems; JAIS - Journal of the Association for Information Systems; JBF - Journal of Business Forecasting; JEIM - Journal of Enterprise Information Management; JMTM - Journal of Manufacturing Technology Management; JMTP - Journal of Marketing Theory \& Practice; JOM Journal of Operations Management; JPSM - Journal of Purchasing and Supply Management; RCIM - Robotics and Computer-Integrated Manufacturing; SCFIJ- Supply Chain Forum: an International Journal; SCMIJ - Supply Chain Management: An International Journal; TJ - Transportation Journal; WASET - World Academy of Science, Engineering \& Technology.

Note: number of citations obtained in January 11, 2014

As depicted in Table 2, just one author published more than two studies on the subject (the full list of the authors are provided in the references of this dissertation). This reinforces the incipience of research on CPFR as there are not yet several global references publishing frequently on the topic. Publications on CPFR are also recent, with the first ones appearing in the late 1990's and with a consolidation along the first decade of this century. The second column presents the number of citations of each article. Google Scholar (GS) was chosen for the citation quotes as it compares favorably with fee-based citation databases such as Thomson ISI Web of Knowledge and Scopus. The required cleaning was performed in GS to avoid duplicate entries (Thomé et al., 2012a). Eight papers had more than 100 citations ( $57.1 \%$ of total citations). The third column depicts the source of the publications with $42.5 \%$ of them concentrated on five leading Business Forecasting and Operations Management (OM) journals: JBF, SCMIJ, IJPDLM, IJPE and IJPR. The last column shows the methodology used in the 
studies. In this dissertation, the papers' methodologies were classified according to the main focus of the paper. According to Eisenhardt (1989), case study is a research strategy which focuses on understanding the dynamics present within single settings. The single case study analyse the operations of a single plant, while multiple case study investigate several sites (Flynn, 1990). Multiple case studies allow for within-case and across-case analysis, being more prone to internal and external validity checks and theory building (Voss et al., 2002). Simulation involves the construction of an artificial environment within which relevant information and data can be generated. This permits an observation of the dynamic behavior of a system under controlled conditions (Kothari, 2004). Papers with the methodology classified as simulations are papers that focusing on the use of simulation to analyse CPFR, comparing different forms of CPFR CPFR vs. other SCC initiatives or CPFR success factors. Papers which treat the subject conceptually have its methodology classified as conceptual model. For Kothari (2004) conceptual research is that related to some abstract idea or theory, and it is generally used to develop new concepts or to reinterpret existing ones. Survey research is a quantitive method, requiring standardized information from and/or about the subjects being studied. The data is collected about a fraction of the population, in such way as to be able to generalise the findings to the population. The data collection is by asking people structured and predefined questions (Pinsonneault and Kraemer, 1993). Five papers are focused on describing and analyzing business practices of the industry and do not use a specific method for this, so its methodology was classified as industry report. One paper focuses in review the literature on quick response SC and its methodology is classified as so.

Case studies and simulations prevail with, respectively thirteen and twelve papers, followed by eleven conceptual models of SCC. Among the case studies, seven are multiple and six are single case studies. It is not surprising that case studies and simulations prevail in a recent field, with the complexities of joint and improved order forecast, demand forecast plans, joint promotions and exception management for replenishment, which are the constituent parts of CPFR. While case studies are particularly adequate to answer questions about why and how (Yin, 1984), simulation is particularly suited to deal with intricate networks of related causalities (Büyüközkan and Vardaloğlu, 2012). Also, the prevalence of conceptual models can be expected in a field characterised by normative and 
prescriptive frameworks for implementation. Five industry reports are found, emphasising the excellence of CPFR processes, although the empirical evidences are weak at best. However, industry reports provide detailed instructions and insights on implementation from a practical standing point that lacks on most academic research on the topic. Survey research is represented in five studies. 


\section{3 \\ Basics of CPFR}

This Chapter presents the first findings of CPFR regarding main definitions and implementation requirements and models. The Chapter also offers a comparison between CPFR and other SCC initiatives.

\section{1. Defining CPFR}

CPFR is a collaborative initiative among SC members intended to improve the relationship among them through a joint planning process that incorporates the sharing of information, risks, benefits/revenues, costs and synchronised forecasts. Based on this collaboration and sharing, the production and replenishment processes are determined (ECR Europe, 2001, Fliedner, 2003, Larsen et al., 2003, Seifert, 2003, Simatupang and Sridharan, 2005, Chen et al., 2007, D’Aubeterre et al., 2008, Chang and Wang, 2008, Danese, 2011).

The CPFR model comprises the processes of collaborative planning, forecasting and replenishment, which, in turn, are subdivided into specific steps or tasks (VICS, 1998). CPFR is established by an agreement among trading partners to cooperate on strategy, tactics and execution by a resolution of exceptions (Derrouiche et al., 2008), thereby eliminating the supply/demand uncertainty through improved communications/collaborations (Attaran and Attaran, 2007). An exception is understood as any deviation from any forecast that is beyond an agreed-upon threshold (Chang and Wang, 2008). Hence, CPFR is a process whereby SC trading partners exchange sales and order forecasts and then correct, adjust, and propose prices and quantities to develop a unique forecast (Caridi et al., 2005, 2006).

CPFR creates value to end customers and improves overall SC performance by providing standardised information and establishing objective plans that allow for an efficient flow of goods based on demand (Shu et al., 2010). Accordingly, CPFR combines the intelligences of multiple trading partners and links the best 
practices in sales and marketing to move the $\mathrm{SC}$ from reactive management to proactive planning and execution (VICS, 2004, Smith et al., 2010, VICS, 2010, Ramanathan, 2014). CPFR integrates business activities that are internal and external to the firm, thereby providing a good collaboration alternative to other SC integration schemes (Chen et al., 2007). For instance, CPFR can embrace retail event/promotions, distribution centre replenishment, store replenishment and assortment planning (VICS, 2004).

CPFR bridges supply and demand among SC trading partners (Stank et al., 1999, Simatupang and Sridharan, 2005, Chang et al., 2007, Sari, 2008b) and results in (i) improved service level while simultaneously reducing inventory and costs (Stank et al., 1999, Larsen et al., 2003, VICS, 2004, Chen et al., 2007, Du et. al., 2009, Smith et al., 2010, VICS, 2010), (ii) promotion of greater integration, visibility and cooperation among partners (Büyüközkan et al., 2009), and (iii) a holistic approach to supply chain management (Sherman, 1998). CPFR aims to optimise the SC performance among SC trading partners from the production and delivery of raw materials to the production and delivery of final products to the end consumer (Danese et al., 2004).

\subsection{1.}

\section{A definition for CPFR}

Based on the extant literature, a comprehensive definition of CPFR is proposed: CPFR is a cohesive bundle of business processes whereby SC trading partners share information, synchronised forecasts, risks, costs and benefits with the intent of improving overall SC performance through joint planning and decision making. Accordingly, CPFR enhances customer demand visibility and matches supply and demand with a synchronised flow of goods from the production and delivery of raw materials to the production and delivery of the final product to the end consumer. The model encompasses different business processes that are subdivided into specific steps or tasks. 


\section{2. Implementing CPFR}

CPFR implementation can take a number of different forms across supply networks according to the depth and scope of the collaboration (Larsen et al., 2003, Seifert, 2003, Danese, 2007, 2011). Several authors stress that CPFR must begin with only a few activities, after which it can gradually expand the scope of collaboration (Barratt and Oliveira, 2001, ECR Europe, 2001, Larsen et al., 2003, Seifert, 2003, Danese, 2011).

Simatupang and Sridharan (2005) use a collaborative SC framework to present the implementation of five critical features that aid trading partners during the initial discussion and implementation of CPFR. These features include (i) a collaborative performance system: the development of metrics that guide the chain members to improve overall performance, (ii) decision synchronisation: the ability to manage critical decisions at the planning and execution levels to optimise SC profitability, (iii) information sharing: the access to proprietary data from the partners, thereby enabling the monitoring of the flow of goods throughout the SC, (iv) incentive alignment: the motivation of the trading partners to reinforce the attainment of overall performance targets by sharing risks, benefits and costs, and (v) integrated SC processes: efficient SC processes that deliver products to end customers in a timely manner at lower costs.

As a first step to implement CPFR, the trading partners should create an environment based on trust and technology (Barratt and Oliveira, 2001). Trust is the most cited enabler in the literature (e.g., Barratt and Oliveira, 2001, Larsen et al., 2003, Attaran and Attaran, 2007, Chang et al., 2007, Chen et al., 2007, Småros, 2007, Chang and Wang, 2008, Büyüközkan et al., 2009, Choi et al., 2010, Smith et al., 2010, Yuan et al., 2010, Büyüközkan and Vardaloğlu, 2012, Yao et al., 2013). Trust refers to the confidence between trading partners that no one of them will exploit vulnerabilities by one of them (Ghosh and Fedorowicz, 2008). It also refers to trading partners treating each other fairly and honestly (Attaran and Attaran, 2007). When trading partners trust each other they tend to communicate openly and it increases information transparency and decrease gaming (Büyüközkan et al., 2009). Furthermore, several authors have mentioned that a lack of trust serves as a barrier to the implementation of CPFR (Barratt and 
Oliveira, 2001, Fliedner, 2003, Attaran, 2004, Thron et al., 2006, Attaran and Attaran, 2007, Chen et al., 2007, Småros, 2007, Thron et al., 2007). According to Barratt and Oliveira (2001), as trust is developed from a long-term perspective, a possible approach is to (i) define a single point of contact for each trading partner, (ii) define the agenda for collaboration, (iii) expand collaborative projects (scope and complexity), (iv) ensure continuous sharing of information and (v) develop a trust-based relationship. To expand the scope of collaboration, several alternatives are to expand the scope of the processes, increase the number of processes, increase the level of detail, increase the product offering, automate the processes, add trading partners and integrate the results (Barratt and Oliveira, 2001).

Büyüközkan et al. (2009) and Büyüközkan and Vardaloğlu (2012) conclude that communication (information sharing) is the most crucial factor for CPFR implementation success. While it is acknowledged that information and communication technology (ICT) enables information sharing (Ghosh and Fedorowicz, 2008), there is no consensus regarding the required level and complexity of ICT, which can vary from simple tools, such as a fax machine, to more advanced Internet-based solutions (Danese, 2006). VICS (2004) and Ramanathan (2014) contend that while ICT can make the process more scalable, it is not essential to the implementation of CPFR.

Top management support (Attaran and Attaran, 2007, Chen et al., 2007, Büyüközkan et al., 2009, Smith et al., 2010, Büyüközkan and Vardaloğlu, 2012, Ramanathan, 2014), internal forecasting processes (McCarthy and Golicic, 2002, Fliender, 2003, Chen et al., 2007, Smith et al., 2010), risk and profit sharing (Chen et al., 2007, Yaun et al., 2010), organisational readiness (Büyükozkän et al., 2009; Büyükozkän and Vardaloğlu, 2012) and proper staff training (Attaran and Attaran, 2007) are also cited as enablers to the CPFR process.

Other barriers to CPFR mentioned in the literature include investments in technology (Fliedner, 2003, Småros, 2007), a lack of internal integration/collaboration (Fliedner, 2003, Småros, 2007, Ramanathan and Gunasekaran, 2014), a lack of a clear understanding of collaborations and SCC's impact from long-term partnerships on profit earnings (Ramanathan and Gunasekaran, 2014), information security and confidentiality (Büyüközkan et al., 2009, Audy et al., 2012, Büyüközkan and Vardaloğlu, 2012), system incompatibility (Audy et al, 2012), over-dependence on technology when 
implementing CPFR, lack of ability to differentiate between with whom to collaborate and in what order (Thron et al., 2006, 2007) and security protocols (Hvolby and Trienekens, 2010).

Larsen et al. (2003) propose the only maturity model for CPFR encountered in this review. The model embraces three CPFR levels: basic (few partners and activities with low transactional costs), developed (increased integration and expanded scope with enhanced responsiveness) and advanced (synchronised planning, promotion, marketing and new product launching). Larsen et al. (2003) contend that the basic CPFR is generally the starting point for other collaboration initiatives. From a long-term perspective, the goal is to reach the advanced stage.

Danese (2011) explains different CPFR configurations based on the following contextual variables: demand elasticity and uncertainty, goals of the process (responsiveness vs. efficiency), number of products (same/different products sold by suppliers and customers), and SC spatial complexity (number of partners and geographical distance). The levels and scope of collaboration (limited and synchronised communications) vary according to the contextual variables rather than as an evolution from basic to advanced CPFR, as predicted by Larsen et al. (2003)'s maturity model.

Several authors cite different numbers of participants in CPFR initiatives. For example, Holmström et al. (2002) posit that mass collaboration is needed, while Büyüközkan et al. (2009) and Büyüközkan and Vardaloğlu (2012) state that it is necessary to select a small number of participants. Ramanathan (2014) concludes that a higher number of trading partners does not mean a higher level of performance. For Audy et al. (2012), the right number of partners depends on the industrial context. Similar to Audy et al. (2012), Danese (2011) states that there is no general rule regarding the number of participants as it is a contingency variable that is specific to the environment and context in which the CPFR is implemented.

\section{3.}

\section{CPFR models}

The literature offers various models that organise CPFR according to processes, steps, activities and tasks. The first model was published by the VICS committee in 1998 in a working paper with best practices and a guideline for 
implementation (Barratt and Oliveira, 2001, Larsen et al., 2003, Danese, 2007, Poler et al., 2008, Du et al., 2009). The different models offered in the literature are introduced in Table 3 and discussed herein. 
Table 3 - CPFR models

\begin{tabular}{|c|c|c|}
\hline Reference & $\begin{array}{c}\text { \# of } \\
\text { steps/tasks }\end{array}$ & Model' descriptions \\
\hline VICS (1998) & 9 & $\begin{array}{l}\text { CPFR is based on a linear process with nine steps: (i) develop front-end agreement, (ii) create joint business plan, (iii) create sales } \\
\text { forecast, (iv) identify exceptions to sales forecast, (v) resolve exceptions to sales forecast, (vi) create order forecast, (vii) identify } \\
\text { exceptions to order forecast, (viii) resolve exceptions to order forecast and (ix) generate order. These nine steps are organised into three } \\
\text { processes: planning, forecasting and replenishment. }\end{array}$ \\
\hline Fliedner (2003) & 5 & $\begin{array}{l}\text { CPFR is established through five iterative steps: (i) creation a front-end agreement, (ii) creation a joint business planning, (iii) } \\
\text { development of forecasts, (iv) sharing forecasts and (v) inventory replenishment. }\end{array}$ \\
\hline VICS (2004) & 8 & $\begin{array}{l}\text { CPFR consists of four activities, each of which is divided into two tasks: (i) strategy and planning: collaborative arrangement and joint } \\
\text { business plan, (ii) demand and supply management: sales forecasting and order planning/forecasting, (iii) execution: order generation } \\
\text { and order fulfilment, (iv) analysis: exception management and performance assessment. }\end{array}$ \\
\hline $\begin{array}{l}\text { Caridi et al. (2005, } \\
\text { 2006) }\end{array}$ & 9 & $\begin{array}{l}\text { This model is based on VICS (1998) and suggests that the process can be improved with autonomous agents. The authors propose two } \\
\text { CPFR models with agent-based models to optimise the negotiation steps (exception management) in the CPFR process. The autonomous } \\
\text { agents are entities that have problem-solving capabilities can therefore propose solutions to solve the exceptions. }\end{array}$ \\
\hline Chang et al. (2007) & 9 & $\begin{array}{l}\text { This model is an augmented CPFR also based on VICS (1998). The authors include in the process an application service provider (ASP) } \\
\text { that uses market information to improve forecast accuracy and replenishment. The process has nine steps: (i) draft agreement, (ii) } \\
\text { develop joint business plan, (iii) forecast sales, (iv) identify unusual sales forecasts, (v) deal collaboratively with unusual items, (vi) } \\
\text { forecast orders, (vii) identify unusual order forecasts, (viii) deal collaboratively with unusual items and (ix) generate order. }\end{array}$ \\
\hline $\begin{array}{l}\text { Chang and Wang } \\
(2008)\end{array}$ & 8 & $\begin{array}{l}\text { The model is based on VICS (2004) with the same four activities; however, it incorporates the DMAIC (define, measure, analyse, } \\
\text { improve and control) cycle from Six Sigma methodology into the demand and supply management activity to improve forecast accuracy. }\end{array}$ \\
\hline Du et al. (2009) & 3 & $\begin{array}{l}\text { This model is based on VICS (1998), though the authors reorganised the model into three steps: (i) development of collaborative } \\
\text { arrangement and preparation of joint business plan, (ii) generation of collaborative sales and order forecast and (iii) generation of order } \\
\text { and execution of shipments. This last step can be subdivided into three separate steps to include collaborative schedule production and } \\
\text { delivery, exception management and execution of shipments. }\end{array}$ \\
\hline Shu et al. (2010) & 11 & $\begin{array}{l}\text { This model is based on VICS (1998), though the authors propose a process with three processes and eleven steps: (i) decompose and } \\
\text { search for a module, (ii) reach a forward collaboration agreement, (iii) create a collaboration plan, (iv) forecast sales, (v) confirm } \\
\text { exceptions in sales forecasts (vi) resolve exceptions in sales forecasts, (vii) order forecasts, (viii) confirm exceptions in order forecasts, } \\
\text { (ix) resolve exceptions in order forecasts, (x) create an order and (xi) produce and service. The three first steps correspond to the } \\
\text { planning process, steps (iv) to (ix) correspond to the forecasting process and the last two steps comprise the replenishment process. }\end{array}$ \\
\hline
\end{tabular}


The 1998 VICS model, depicted in Figure 1, begins with the creation of a front-end agreement that establishes the scope and assigns roles, responsibilities, checkpoints, and escalation procedures with respect to collaboration. Furthermore, it develops a scorecard to track SC metrics and establishes incentives (Barratt and Oliveira, 2001, Danese et al., 2004, Ireland, 2005, Simatupang and Sridharan, 2005, Cassivi, 2006, Danese, 2007, D'Aubeterre et al., 2008). Objectives and requirements of all trading partners are discussed and clarified (Caridi et al., 2005, Cassivi, 2006), and a joint business plan is created to identify the significant events that affect supply and demand in the planning period (e.g., promotion, product introductions), logistics parameters (e.g., safety stocks, frozen periods, delivery dates, order minimums and multiples), the information to be exchanged and the exception criteria to resolve planning variances between the trading partner's demand forecasts (Ireland, 2005, Simatupang and Sridharan, 2005, Cassivi, 2006, Danese, 2007, Chang and Wang, 2008, Shu et al., 2010). During the forecasting process, the volumes of sales are forecast, the differences among the trading partners' volumes (exceptions) are discussed and a mutually agreed sales forecast is created. The combination of sales forecasts, inventory levels, inventory strategies and other information make it possible to generate a specific order forecast that allows the seller simultaneously to (i) allocate production capacity against demand and (ii) minimise safety stock. The exceptions are again discussed, and a common order forecast is created. Finally, the replenishment plan is created, thus transforming the order forecast into a committed order (Simatupang and Sridharan, 2005, Caridi et al., 2005, Danese, 2007).

Figure 1 - VICS first model

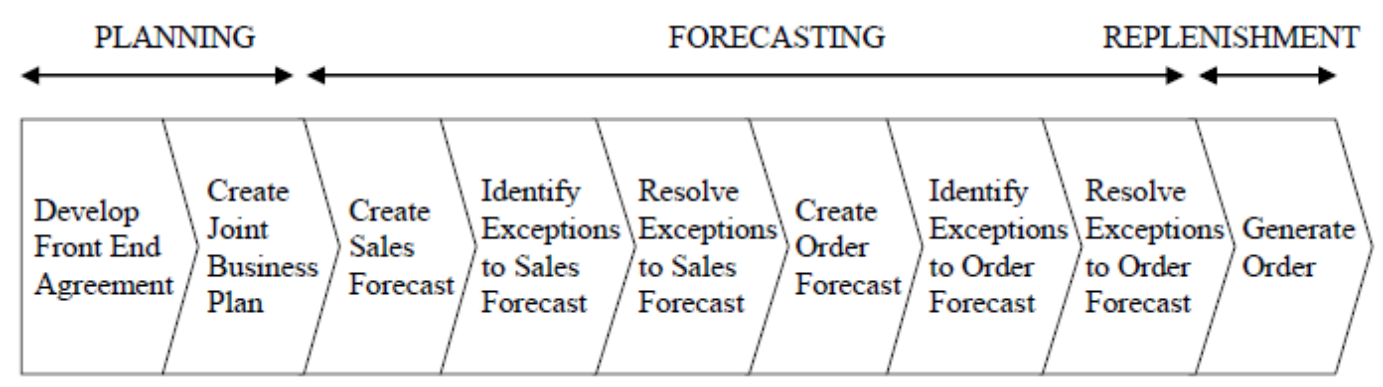

Source: Danese et al. (2004)

The VICS model proposed in 1998 was used as the basis for many academic models presented in the literature, as discussed herein. 
Caridi et al. (2005, 2006) propose two CPFR models based on VICS (1998). The models embrace autonomous agents with varying degrees of capabilities - the advanced model and the learning model - both of which are compared with the traditional CPFR model without agents. Caridi et al. $(2005,2006)$ argue that the order and forecast resolved exceptions steps can be optimised and automated with the use of autonomous agents. The proposed models use the autonomous agents to optimise the exchange of information as well as the collaboration and negotiations among trading partners. In the advanced model, all variables are monitored by the autonomous agent who proposes solutions according to the rules pre-defined in the front-end agreement. In the learning model, the autonomous agent analyses system parameters and rewrites the collaboration rules (from the front-end agreement). Through simulation, the authors conclude that CPFR models with intelligent agents exhibit better results compared to those of the traditional CPFR model.

According to Chang et al. (2007), the VICS first model does not adequately address the questions of market strategy and collaborative marketing, as it does not consider the behaviours of the competitors. Accordingly, the authors propose an extended CPFR (A-CPFR) model, which is also based on VICS (1998), that includes an application service provider (ASP) within the model. The ASP collects information from POS from the major chain stores, supermarkets, wholesalers and web sites as well as the databases of major news sites. The ASP provides information to the planner about market trends, such as competitors' sales promotions, and this information is used to adjust the replenishment programme of CPFR. The SC can then respond promptly to temporary fluctuations in market demand. With simulations, they (Chang et al., 2007) confirm that A-CPFR has a higher level of forecasting accuracy than the CPFR model.

Du et al. (2009) consider the VICS model far too complicated to implement and therefore propose a new model that combines the CPFR concept with the collaborative transportation management (CTM) concept. CTM aims to reduce or eliminate the inefficiencies in the transportation process through collaboration. In the first step, the development of collaborative arrangement and preparation of joint business plan, the trading partners define the roles, responsibilities and timelines. A CPFR group is established and a merchandise plan is agreed upon. In 
the collaborative sales and order forecast generation step, the sales forecast is developed, the exceptions are resolved and the sales forecast is converted to order forecast for a frozen period. The last step, which includes order generation and the execution of shipments, is divided into three tasks: the collaborative scheduling of production and delivery, exception management and execution of shipments. The manufacturers in the partnership use the order forecast to provide a capacity commitment, and they generate delivery data. If the delivery data do not correspond to the order forecast, the CPFR group resolves the exception. Finally, the CPFR group manages the order process. That is, they receive and monitor the forecast and the product availability data.

Shu et al. (2010) argue that credit risk is a factor that can disrupt an agile value enterprise (AVE) and, as a result, the SC. An AVE is composed of independent producers and customers who form a temporary network that share technology and meet the demand of the market by means of information technology. Based on the CPFR model, the authors propose a credit granting guarantee approach in an AVE SC. Under this mechanism, credit risk in the AVEs can be optimised such that the AVE chain can match the working mechanism of CPFR in its capacities of real-time resource sharing, n-tier resource allocation, mission assignment, control, and supervision. This process is organised into three stages: planning, forecasting and replenishment. The planning stage refers to module decomposition, the search for suitable partners and the establishment of a front-end agreement and a joint business plan. The forecasting process encompasses the sales and order forecast, exceptions resolution and production allocation among AVE members. Orders and manufacturing plans are developed, and service is provided under the replenishment process. In the proposed AVECPFR model, companies can assess the information, analyse credit granting issues and construct a selection model for collaborative credit granting of the AVE SC.

Rather than adapting the VICS model, Fliedner (2003) proposes a cyclic and iterative five-step CPFR process: (i) the front-end agreement specifies objectives, resource requirements and expectations of confidentiality, (ii) the joint business planning process coalesces the individual corporate strategies and creates a partnership strategy, (iii) the joint business plan sets a common calendar and establishes exception criteria for handling planning variances between trading partners' forecast demands, (iv) trading partners develop and share their demand 
forecasts, and exceptions are analysed, (v) the order forecast becomes the actual order that starts the replenishment process.

In 2004, VICS reviewed the original model that changed the linear process to a cyclic one with four activities and eight tasks. This second model is depicted in Figure 2. It is a continuous improvement model that focuses on effects (VICS, 2004). In this new model, VICS reorganise the three processes (planning, forecasting and replenishment) into four collaboration activities (strategy and planning, demand and supply management, execution, and analysis). The original nine steps are reorganised into eight tasks. The steps provide the sequence, but as emphasised by VICS, there is no predefined sequence to follow in this new model and most companies are involved in all steps at any point in time. Companies may also focus on a subset of the four activities, which is referred to as "CPFR Lite". In this case, the rest of the processes are performed through the conventional processes. In other words, strategy and planning is similar to the first two steps in the VICS (1998) model; demand and supply refers to the forecasting of the end consumer's order and shipment requirements. Execution corresponds to the placement of orders, preparation and delivery of shipments, reception and stock of products on retail shelves, record of sales transactions and payments. When VICS incorporates the order fulfilment in the model, it also includes the distributors as participants of CPFR. Esper and Williams (2003) and Du et al. (2009) regard the inclusion of order fulfilment after the order generation in CPFR under the concept of CTM. Esper and Williams (2003) argue that order fulfilment should be included because without the ability to effectively develop shipment forecast, the order planned during the CPFR process could not be accurately executed. During analysis, key metrics to evaluate the achievement of business goals, to formulate alternative strategies and to resolve exceptions are calculated (VICS, 2004). While the first model is a rigid process that requires companies to follow a set path to implement each successive activity, the new model is an attempt to create a more flexible process (Burnette, 2010). It is suggested that the 2004 VICS model incorporates lessons from experience and addresses certain criticisms of the first model (VICS, 2004). 
Figure 2 - VICS second model

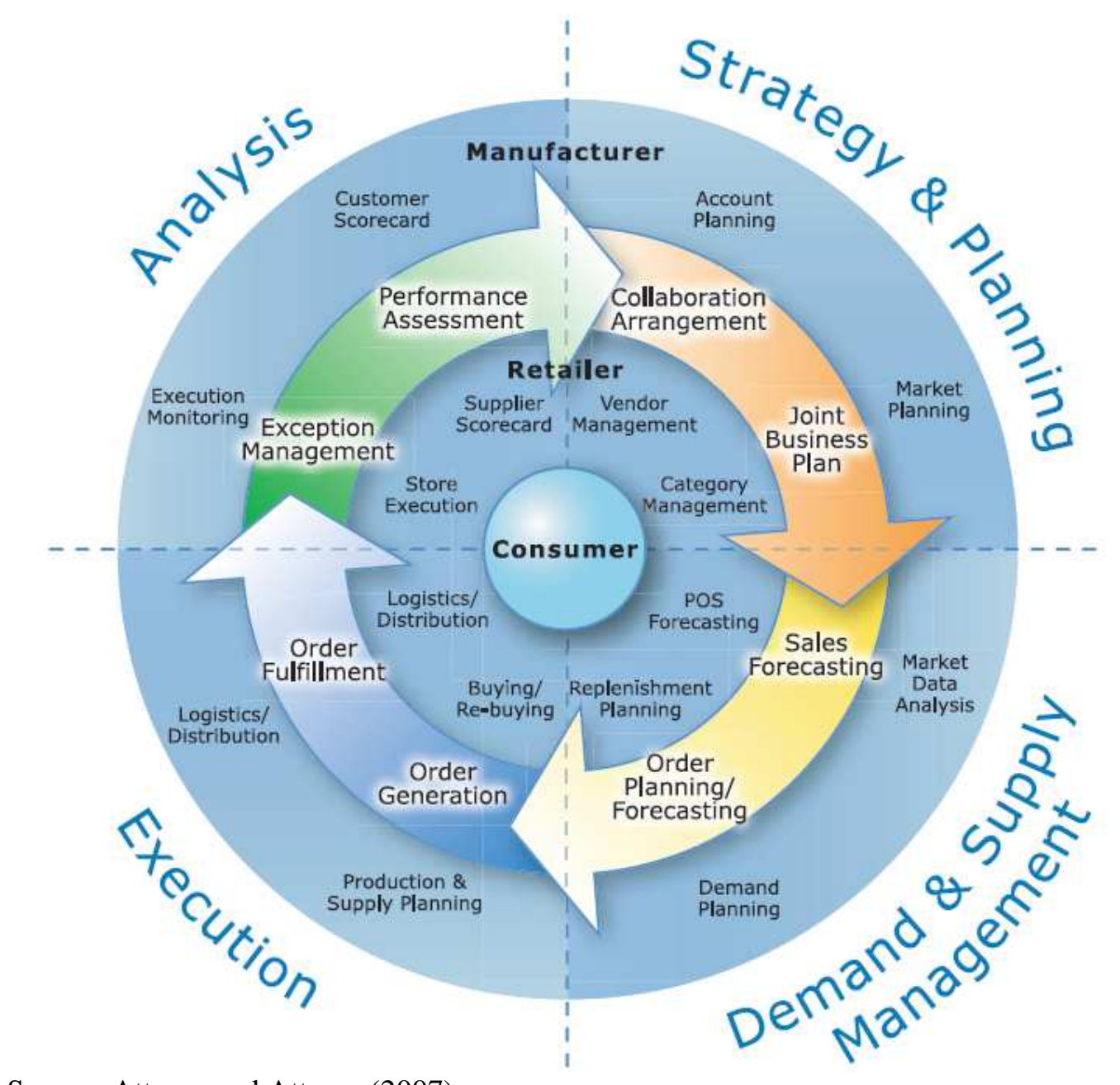

Source: Attaran and Attaran (2007)

Chang and Wang (2008) propose a unified CPFR model based on the second model of VICS that incorporates the DMAIC (define, measure, analyse, improve and control) cycle from Six Sigma methodology into the demand and supply management activity. This proposed model is intended to improve the performance of collaborative forecasts, which is the main difference between the proposed model and the VICS model. The defined module determines the type of data to be shared, and the measurement module collects the sales data. The forecast accuracy is evaluated using the mean absolute percentage error (MAPE), and data patterns are analysed using statistical tools. The improved module identifies and implements changes in the process to improve overall forecasting accuracy, and control charts are used to monitor the forecasting accuracy. When Chang and Wang (2008) applied the proposed model in a case study, the average 
MAPE value of products declined by more than $10 \%$. Their case study also reports financial benefits in terms of cost reductions and revenue increases.

In summary, most alternate CPFR models are variations of the original 1998 VICS model. Despite its relevance to CPFR practice and the related literature, several authors contend that the 1998 VICS model is too rigid and cannot be implemented as a "slavish step-by-step process" (ECR Europe, 2001, Larsen et al., 2003, Seifert, 2003, Burnette, 2010), is too detailed or too comprehensive (McCarthy and Golicic, 2002), is too complicated to be implemented (Du et al, 2009), lacks collaborative performance systems and incentive alignments as it does not restructure the distribution of costs, risks and benefits and it does not establish common metrics to evaluate activities (Simatupang and Sridharan, 2005). The 2004 VICS model is an attempt to quiet many of these critics, and in turn, it is also used as a reference for other academic models, such as Chang and Wang (2008). In 2010, VICS integrated the CPFR and sales and operations planning (S\&OP) constructs into the integrated business planning (IBP) concept (Baumann, 2010, Smith et al., 2010, VICS, 2010). The 2010 VICS guidelines posit that S\&OP is the best model for internal collaboration, while CPFR is the best model for external collaboration. Thus, the IBP concept synchronises operations across individual units in the SC using an internal cross-functional process. As a new paradigm, the IBP process aligns companies' operational plans with their long-term business strategies and financial plans (Baumann, 2010).

\section{4 . CPFR vs. other SCC initiatives}

The literature offers several examples of SCC beyond CPFR, such as: VMI, $\mathrm{ECR}, \mathrm{CR}$, quick response (QR), continuous replenishment policy (CRP), synchronised consumer response (SCR), rapid replenishment (RR), centralised inventory management (CIM), accurate response (AR) and joint managed inventory (JMI) (Barratt and Oliveira,2001; Danese, 2006b; Chen et al., 2007; Småros, 2007; Derrouiche et al., 2008; Yuan et al., 2010; Ramanathan and Gunasekaran, 2014).

CPFR emerges with the aspiration to cover gaps from previous SCC initiatives, such as VMI and ECR, with the incorporation of promotion plans in 
sales forecasts, increased responsiveness to changing demand patterns and better coordination along the SC (Barratt and Oliveira, 2001). CPFR takes a more comprehensive approach than prior SC initiatives with respect to the planning of promotions, sales and orders forecast; synchronisation of plans between trading partners; the making of joint decisions and the management of exceptions (Danese, 2011). Attaran (2004) contends that before CPFR financial plans took precedence over forecasting, SCC initiatives resulted in high inventory levels, low order fill rates, and increased expedited activities. According to Burnette (2010), CPFR is an exception-driven process while the other collaborative initiatives are more data driven and exceptions are not part of the process. Through exception management, trading partners can collaboratively review sales and order forecasts (Du et al., 2009, Burnette, 2010), and they can do so on a large scale (Du et al., 2009).

CPFR can be viewed as a second generation of ECR (Stank et al., 1999, Larsen et al., 2003, Seifert, 2003, Ramanathan, 2014). For Holmström et al. (2002), ECR is a process that combines efficient replenishment and category management but fails to synchronise plans among trading partners.

Some authors refer to CPFR as an evolution from VMI and CR/CRP (Barratt and Oliveira, 2001, Attaran, 2004, Cassivi, 2006, Thron et al., 2006, Attaran and Attaran, 2007, Danese, 2011) as CPFR captures the advantages of such programmes while adding the collaborative mechanism to facilitate information exchange in a multi-tiered SC (Cassivi, 2006). Some retailers discontinued their VMI project because they were unsatisfied with the results, mainly due to the lack of collaboration, the forecasting ability of the suppliers and the vendors' inability to address product promotions (Sari, 2008b, Yuan et al., 2010). Despite the fact that CPFR and VMI are different initiatives in SC, they can be implemented together in some cases. Holmström et al. (2002) suggest that replenishment methods such as VMI can help the trading partners to implement a more integrated CPFR model. Danese et al. (2004) describe two case studies where the companies successfully implemented CPFR and utilised VMI to aid in the replenishment of the distribution centres. According to VICS (2004), CPFR is compatible with VMI and traditional ordering processes. The difference in these alternatives is the role played by the lead company in sales forecasting, order 
planning/forecasting and order generation. Thron et al. (2006, 2007) successfully simulate a CPFR process where retailers are replenished through VMI.

Studies comparing different SCC initiatives and their impact on performance are depicted in Table 4, which highlights research methodology, SCC initiatives, performance dimensions and primary findings. It is not surprising that simulation and mathematical programming are the methodologies of choice as they are responsible for the economy of large investments required in real life SC experiments (Audy et al., 2012; Ramanathan, 2014).

Results from these studies indicate that CPFR has better results than other SCC initiatives. However, Sari (2008a, 2008b) concludes that under some conditions the gains in performance of CPFR over VMI does not justify the additional costs required for CPFR. Yuan et al. (2010) find that JMI's performance is nearly comparable to that of CPFR and that, as a result, the decision between the two depends on several factors, such as ICT availability, trust between trading partners, format/type of financing system and the geographical spread of retailers. These conclusions corroborate the findings of McCarthy and Golicic (2002), who find that in certain cases, alternative collaborative forecasts can obtain better results with less investment than that provided by CPFR. 
Table 4 - Studies comparing different SCC initiatives

\begin{tabular}{|c|c|c|c|c|}
\hline Reference & Methodology & SCC initiatives & Performance dimensions & Findings \\
\hline Sari (2008a) & Simulation & VMI and CPFR & $\begin{array}{l}\text { SC costs and customer } \\
\text { service level }\end{array}$ & $\begin{array}{l}\text { CPFR is more sensitive to inventory inaccuracy in terms of cost savings and } \\
\text { customer service. Although CPFR has a better performance than VMI, when } \\
\text { the inventory inaccuracy rate increases, the additional performance provided by } \\
\text { CPFR over VMI is significantly reduced. Both initiatives are more sensitive to } \\
\text { inaccurate inventory information when customer demand uncertainty is low } \\
\text { and/or when lead times are short. }\end{array}$ \\
\hline Sari (2008b) & Simulation & VMI and CPFR & $\begin{array}{l}\text { SC costs and customer } \\
\text { service level }\end{array}$ & $\begin{array}{l}\text { CPFR benefits are always higher than VMI, but in some conditions (short lead } \\
\text { time and/or tight manufacturing capacity) the gap in the performance is not } \\
\text { high. }\end{array}$ \\
\hline Yuan et al. (2010) & Dynamic Simulation & VMI, JMI and CPFR & $\begin{array}{l}\text { Inventory and } \\
\text { responsiveness }\end{array}$ & CPFR has the better performance, but it is very close to JMI. \\
\hline$\overline{\text { Audy et al. (2012) }}$ & $\begin{array}{l}\text { Mathematical } \\
\text { programming }\end{array}$ & CR, VMI and CPFR & Profitability & $\begin{array}{l}\text { CPFR generates the largest system profit, followed by VMI and CR. However, } \\
\text { analysing the profit separately for manufacturer and wholesaler, CR presents } \\
\text { the highest profit to the wholesaler, while CPFR still produces the highest } \\
\text { profit to the manufacturer. When the manufacturer shared part of the } \\
\text { transportation savings with the retailer, CPFR became the best option for both } \\
\text { trading partners. }\end{array}$ \\
\hline
\end{tabular}


There are differences in performances even among different CPFR configurations. Chen et al. (2007) compare four different CPFR configurations and a non-collaborative SC. The configurations differ according to (i) who takes the lead in the steps of sales forecasting, order forecasting and order generation, (ii) information sharing and (iii) handling of exceptions. Nobody takes the lead for sharing information or managing exceptions in the non-collaborative SC. In scenario 1 , the retailer is responsible for all three steps - sharing promotion and sales information and managing sales and order forecast exceptions. In scenario 2, sales forecast are led by the retailer while order forecasts and generation are led by the manufacturer and information regarding promotion, sales, inventory and capacity, sales and order forecast exceptions is handled by the retailer. In scenario 3 , sales and order forecasts are led by the retailer, order generation is led by the manufacturer, and information on promotion, inventory, sales and order forecast exceptions is shared by the retailer. In scenario 4, the manufacturer assumes responsibility for all three steps, sharing inventory and capacity information and managing sales and order forecast exceptions. All the CPFR-based SCs outperformed the non-collaborative SCs with respect to service level, fulfilment rate, cycle time and costs. Among CPFR-based SCs, the best performer was the scenario where more information was exchanged among partners. The authors suggest that the selection of the more adequate collaboration scenario is dependent upon the knowledge and technology level of trading partners.

As there are many SCC initiatives that can improve SC performance, there is no rule of thumb regarding how to choose the best option. Derrouiche et al. (2008) apply information systems theory to CPFR and propose an information/managerial framework to identify the information flow demand and constraints imposed upon trading partners. Tyan and Wee (2003) suggest that the choice of CPFR configuration may vary according to the power structure of the retailer-supplier relationship such that CPFR is the better choice when each of the two partners possesses a high degree of power, VMI is the choice when the supplier overpowers the retailer, and QR is the choice when the balance of power favours the retailer. CMI, ECR and CRP occupy intermediate positions in this framework. 


\section{4 \\ Results and discussions}

The results are presented in two broad categories: literature search synthesis framework and study descriptors.

\section{1.}

\section{A literature search synthesis framework}

Despite its recent origin and relatively few publications on the topic, CPFR is conceptually broad, encompassing several planning and management processes within and among firms. The framework depicted in Figure 3 is an aide to assemble and organise the review. It is based on an original framework proposed by Thomé et al. (2012a), expanded with information from explanatory theories of RBV and RDT (Ramanathan and Gunasekaran, 2014), maturity models (Larsen et al., 2003) and contingency research (Danese, 2011) applied to CPFR. The structure of the framework embraces all the constitutive elements required to describe individual CPFR elements, their relationships and impact upon performance. The adapted framework adds the dimension of SCC to the original Thomé et al. (2012a)'s firm-centered framework. It also adds the vertical functional role of CPFR in bridging business and corporate strategic plans of individual firms with joint SC operations. CPFR results feedback to inputs. Important contextual variables emanated from the contingency theory were added, such as number of SC partners, product characteristics and SC goals (Danese, 2011). This model is consistent with Simatupang and Sridharan's (2004) conceptual model, showing an outcomes cell revised from the original framework that now comprise shared SC processes, with a feedback loop to actual performance. Changes from the original framework had better portray the specific results expected from CPFR. It equally contemplates the evolutionary approach embedded in CPFR maturity models (Larsen, 2003) with the inclusion of the level of collaboration in the meetings and collaborations cell, which was absent from Thomé et al. (2012a)'s original framework. For the RBV and RDT of the firm, 
companies engage in CPFR processes with inimitable and unique resources to gain competitive advantages (Ramanathan and Gunasekaran, 2014). SC shared strategies, the definition of the level of collaboration, use of resources/inputs, as well as resources and information sharing are essential aspects of RBV and RDB theories integrated into this revised framework.

From a contingency theory's standing point (Sousa and Voss, 2008), one can expect that CPFR would behave differently in different contexts. The most relevant contextual variables researched areregion/country, industry type, product characteristics (such as diversity, elasticity of demand and life-cycle), level of product aggregation, manufacturing strategy (e.g., make-to-stock/MTS, make-toorder/MTO, assemble-to-order/ATO), hierarchical planning (from strategic to operational), planning horizons, goals of CPFR (responsiveness versus efficiency), number of SC partners and market dynamics. Inputs are information on demand, source/delivery, inventory/production and finance. Structure and processes are described in the four main categories of meetings and collaboration, organisation, ICT; and metrics. Meetings and collaboration among firms are described through the number and type of participants; trust and confidence as well as the length of their relationships; level of collaboration (limited or full) and meeting regularity. Organisational variables are analysed through the lenses of organisational readiness for CPFR and how the teams and processes are organised (steps, agenda, purpose and reach). Technologies for CPFR are regrouped in general information systems as Enterprise Resource Planning, analytics (advanced planning software, models, simulation) and other ICTs (e.g., EDIs, web portals). Metrics aims at measuring end results (grouped into market related, operational and financial) as well as the CPFR process in itself. The main expected outcomes are collaborative plan, forecast and replenishment. It is expected that outcomes would impact upon end results in all three broad areas of market-related, operational and financial results. CPFR results feedback to inputs. This model is consistent with Simatupang and Sridharan's (2004) conceptual model for SCC and with Danese's theoretical contingency framework for CPFR (Danese, 2006a). 
Figure 3 - Literature search synthesis framework

\section{BUSINESS \&CORPORATE STRATEGICPLANS FROM SC} MEMBERS

\section{CONTEXT}

\begin{tabular}{|l|}
\hline Region / Country \\
Industry Type \\
Product-Characteristic \\
Product aggregation \\
Manufacturing \\
Strategy \\
Hierarchical planning \\
Planning horizon \\
Goals \\
\# of SC partners \\
Market \\
dynamics
\end{tabular}

\section{STRUCTURE AND PROCESSESS}

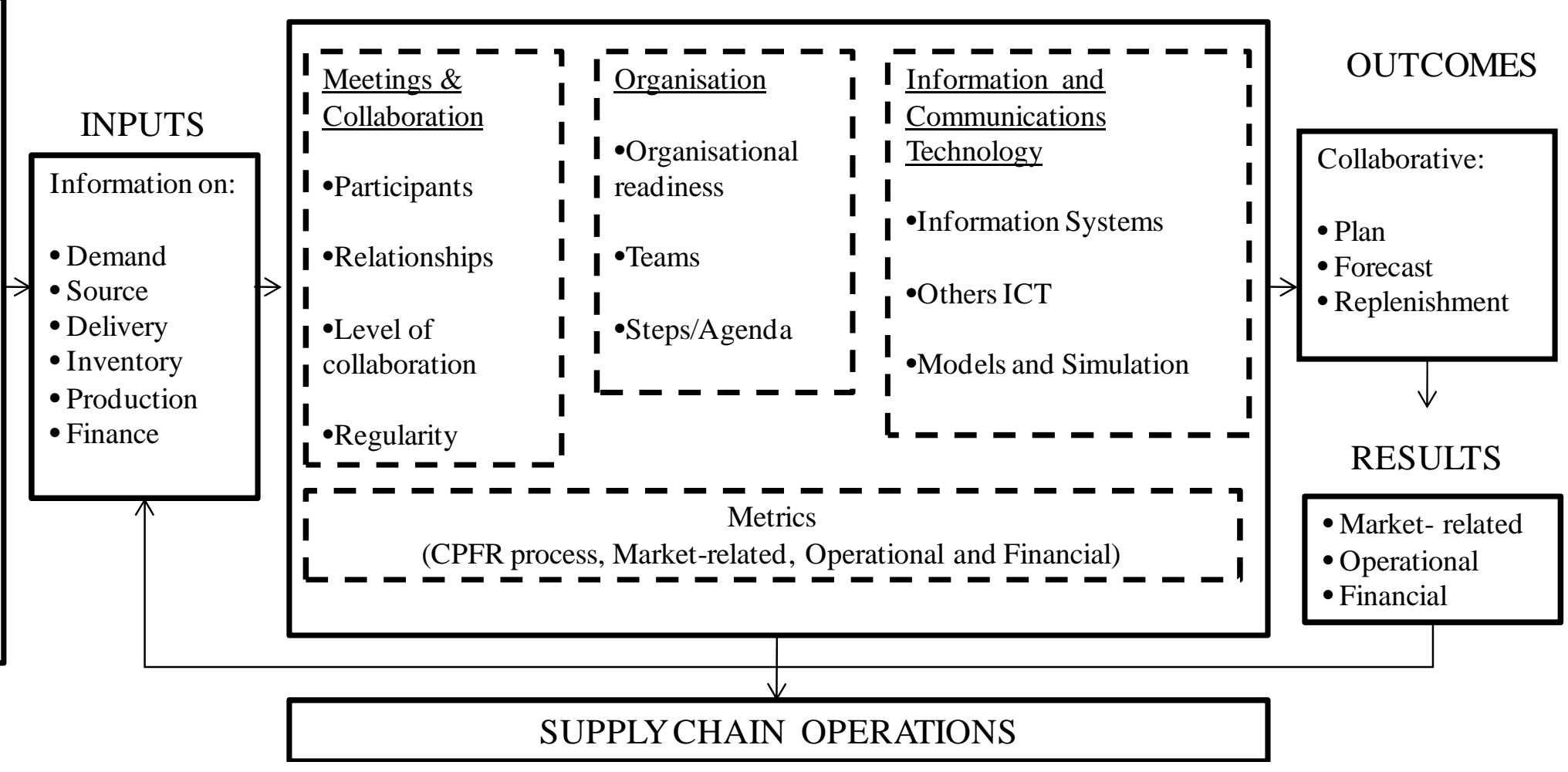

Source: elaborated by the author adapted from Thomé et al., 2012a 


\section{2. \\ Study descriptors}

The following sub-sections present a review of the research and the key findings organised by the framework elements.

\subsection{1. \\ Business and corporate strategic plans}

The large majority of the CPFR models start with the development of a collaborative arrangement and a joint business plan. A collaboration initiative requires partners to work more closely with a joint vision to align process and capabilities (Büyükozkän et al., 2009). In order to align corporate strategies, benefits arising from the collaboration and risk sharing, the objectives for CPFR have to be mutually agreed on (Büyükozkän et al., 2009, Büyükozkän and Vardaloğlu, 2012). To achieve this level of alignment, several models determined a specific step to develop a front-end agreement, which includes the guidelines and procedures specifying how the CPFR process is to be carried out and how the partners create a partnership strategy based on their individual strategies (Barratt and Oliveira, 2001, Fliedner, 2003, Danese et al., 2004), the information to be shared (Seifert, 2003), the CPFR's goals and objectives (Stank et al., 1999, Seifert, 2003, Caridi et al., 2005, Cassivi, 2006), with common metrics and performance measures jointly defined (Barratt and Oliveira, 2001, Danese et al., 2004, Ireland, 2005, Cassivi, 2006, Simatupang and Sridharan, 2005, Danese, 2007, D'Aubeterre et al., 2008). With these metrics it is possible to identify bottlenecks in the SC like excess inventory, gaps in the process and to monitor and evaluate the impact of CPFR on performance (Danese, 2007, Büyükozkän et al., 2009). After the front-end agreement, a joint business plan is created to identify significant events that affect supply and demand in the planning period, determine the items for collaboration, define logistics parameters to monitor the process (e.g., lead-time, delivery dates, order intervals, minimum order quantity, frozen periods) and exception criteria for handling variances in the forecast or orders volumes (Stank et al., 1999, Barratt and Oliveira, 2001, Fliedner, 2003, Danese, et al., 2004, Caridi et al., 2005, Ireland, 2005, Simatupang and Sridharan, 2005, Cassivi, 2006, Danese, 2007, D'Aubeterre et al., 2008, Chang and Wang, 
2008, Du et al., 2009, Büyükozkän et al., 2009, Shu et al., 2010, Büyükozkän and Vardaloğlu, 2012). The lack of discipline to execute this first step is considered a barrier to a proper execution (Barratt and Oliveira, 2001). Larsen et al. (2003) argues that the front end agreement is not mandatory and could advantageously be replaced by "private agreements" (credible commitments and joint investments). Furthermore, the steps and modalities for implementation may vary across industries and SC networks (ECR Europe 2001, 2002, Larsen et al. 2003, Seifert 2003, Danese, 2011).

\subsection{2. \\ Context}

There are reports of CPFR implementation in different contexts. Collaboration varies in scope and configuration according to contextual variables, among which market dynamics (demand uncertainty/unpredictability), goals (responsiveness versus efficiency), product diversity (same or different products) and number of partners (spatial complexity) seems to be the most relevant (Danese, 2011). Countries of implementation vary, with most studies conducted in Europe and United States of America (USA), but Canada, India, Mexico, Philippines, Taiwan and the Middle East are represented as well. The cases reported in the beginning of CPFR emanated from the food, apparel and general merchandise retail industries (Fliedner, 2003), although it was later expanded to such a diversified array of industries astransportation, healthcare, automotive, mechanical equipment, agriculture, pharmaceutical, computers, packaging (Attaran, 2004, Danese et al., 2004, Ireland, 2005, Cassivi, 2006, Thron et al., 2006, Danese, 2007, D’Aubeterre et al., 2008, Sari, 2008b, Danese, 2011, Yao et al., 2013, Ramanathan, 2014). Some authors argue that CPFR methodology is applicable to any industry (Fliedner, 2003, Ireland, 2005). Larsen et al. (2003) quote that CPFR is more appropriate for price-driven, highly differentiated products operating a many to many relationship in the SC. Product characteristics are also viewed as enablers in CPFR such as: highly differentiated or branded products (Attaran, 2004, Attaran and Attaran, 2007, Danese, 2007); short product life cycles (Chen et al., 2007, Sari, 2008b, Yuan et al., 2010); high elasticity of demand related to product promotions (Danese, 2011); innovative products 
(Fliedner, 2003); high volume/high value products compensating for high implementation costs (Stank et al., 1999, Ghosh and Fedorowicz, 2008).

Except in Holmströmet al. (2002), Larsen et al. (2003) and Danese et al. (2004), CPFR implementation is reported for stock keeping units (SKUs), although the number of SKUs included in the process may vary from a single product to as many as 100 plus related products (D’Aubeterre et al., 2008), which is quoted as an impediment for a successful implementation (Fliedner, 2003). But in most successful pilots only few products were included (Chang and Wang, 2008).

CPFR planning horizon is also variable from one SC network to another. A typical planning horizon for CPFR is provided by Småros (2007), in a single case study from the European grocery sector. It varies from one to four months for planning; two weeks to one month for forecasting and one day to one week for replenishment. Småros (2007) finds that due to different planning horizons and product aggregation levels, forecasting and collaboration needs differ for retailers and suppliers. Other papers discuss the planning horizon for CPFR: monthly planning and weekly production (Thron et al., 2006); operational planning in the 0-3 month interval, tactical planning every 2-6 month and strategic planning in a 6-12 month basis (Smith et al., 2010); time horizon is linked to the corporate strategy on a 18-24 month interval in a rolling basis (Baumann, 2010). Other authors refer to a general long versus short term horizon for CPFR (Stank et al., 1999, Fliedner, 2003, Shu et al., 2010, Lapide, 2010).

Case studies show that CPFR can be equally effective under different manufacturing strategies: MTS (Chang and Wang, 2008); MTO and MTS (Danese et al., 2004); MTO, MTS and ATO (Danese, 2007, 2011), within a planning hierarchy that covers both strategic-tactical levels and operations (inventory levels and replenishment). However, CPFR generalisation to other strategies (e.g., buy-to-order or engineering-to-order) is not warranted (Danese, 2007).

CPFR collaborations can be classified in two dimensions: the depth of collaboration (communication, limited and full collaboration) and the number of interacting units (few/several) (Danese, 2007). The contextual factors included in the theoretical framework proposed by Danese are goals or "the reasons driving companies towards CPFR implementation” (e.g., efficiency as cost reduction, 
management of lead times and schedules; or responsiveness to customers), product/market characteristics (products type, characteristics of demand, promotions), high/low spatial complexity of SC networks (distance), number of potential partners, and CPFR development stage (Danese, 2006b, 2007, 2011). The contingency theory posits that the strategy and the environment will impact upon organisational processes and structure, which in turn affects performance (Sousa and Voss, 2008). Danese (2011) identifies four contextual variables analysing a multiple ten case study of SC network collaboration that she hypothesises could explain variations in SCC: (i) demand uncertainty/unpredictability measured by high/low demand elasticity in-response to promotions; (ii) goals of companies involved (responsiveness and efficiency); (iii) product diversity (if companies sell the same or different products); (iv) supply network spatial complexity (low/high). The effect of contextual variables is cross classified with levels of collaboration (communication, limited collaboration through joint decisions and full collaboration through synchronised plans) and the number of business areas and processes involved in the SC integration. For a full collaboration network to exist, all of the following should apply: the main goal is responsiveness, companies sell the same product, demand elasticity is high and supply spatial complexity is low. Limited collaboration occurs when the goal is still responsiveness but any of the other necessary conditions is lacking. Communication approaches applies to efficiency driven SC networks. From a contingency theory perspective, the expectation in maturity models that companies will tend to use advanced CPFR collaboration as the process matures is not verified. An important research lead from contingency research is that depending on context, companies might choose not to integrate if for example the costs outweigh the benefits (Danese, 2011).

\subsection{3.}

Inputs

Study descriptors of inputs are presented in Table 5, classified in the categories of demand, inventory/production, source/delivery and finance. Source and delivery are regrouped because they can both apply to the same focal company, depending if upstream or downstream flows are analysed. 
Demand related inputs are grouped into information on sales, forecast, competitors' actions, functional plans and marketing actions: POS and consumption data, sales forecast, sales trends, seasonality, promotion plans, new product introduction and changes in prices. Inputs from the supply side are inventory level and policies, production capacity and functional plans. Source/delivery are subdivided into service level target, functional plans, shipments, delivery lead-time and transportation status: orders forecasts and order planning data, order shipments and to a lesser extend distribution forecasting and scheduling. Financial data is absent in most cases, appearing as generic financial data and flows (Caridi et al., 2006) or gross margin deemed necessary to evaluate mutual success in CPFR initiatives (Simatupang and Sridharan, 2005). Appenix I also presents the CPFR inputs. 
Table 5 - Classification of inputs to the CPFR process

\begin{tabular}{|c|c|}
\hline Type of Inputs & References \\
\hline \multicolumn{2}{|l|}{ Demand } \\
\hline $\begin{array}{l}\text { Information on sales (current \& } \\
\text { past demand) }\end{array}$ & $\begin{array}{l}\text { Stank et al. (1999), Barratt and Oliveira (2001), Holmström et al. (2002), Larsen et al. (2003), Caridiet al. (2005), Simatupang and } \\
\text { Sridharan (2005), Caridi et al. (2006), Danese (2006b), Thron et al. (2006), Attaran and Attaran (2007), Chang et al. (2007), Chen et al. } \\
\text { (2007), Danese (2007), Småros (2007), Thron et al. (2007), Chang and Wang (2008), D'Aubeterre et al. (2008), Ghosh and Fedorowicz } \\
\text { (2008), Poler et al. (2008), Sari (2008a), Sari (2008b), Büyüközkan et al. (2009), Du et al. (2009), Choi and Sethi (2010), Shu et al. } \\
\text { (2010), Yuan et al. (2010), Danese (2011), Audy et al. (2012), Büyüközkan and Vardaloğlu (2012), Yao et al. (2013), Ramanathan and } \\
\text { Gunasekaran (2014) }\end{array}$ \\
\hline Sales/Demand Forecast & $\begin{array}{l}\text { Fliedner (2003), Danese et al. (2004), Caridi et al. (2005), Simatupang and Sridharan (2005), Caridi et al. (2006), Danese (2006b), Thron } \\
\text { et al. (2006), Attaran and Attaran (2007), Chang et al. (2007), Chang and Wang (2008), D'Aubeterre et al. (2008), Ghosh and Fedorowicz } \\
\text { (2008), Sari (2008a), Sari (2008b), Du et al. (2009), Baumann (2010), Choi and Sethi (2010), Shu et al. (2010), Danese (2011), Audy et } \\
\text { al. (2012), Büyüközkan and Vardaloğlu (2012), Yao et al.(2013) }\end{array}$ \\
\hline $\begin{array}{l}\text { Demand impacts (e.g., } \\
\text { competitors' actions) }\end{array}$ & $\begin{array}{l}\text { Danese et al.(2004), Danese (2006b), Chang et al. (2007), Småros (2007), Thron et al. (2007), D'Aubeterre et al.(2008), Shu et al.(2010), } \\
\text { Danese (2011) }\end{array}$ \\
\hline Functional plans & $\begin{array}{l}\text { Stank et al. (1999), Danese et al. (2004),Simatupang and Sridharan (2005), Danese (2006b), Danese (2007), Småros (2007), Thron et al. } \\
\text { (2007), D'Aubeterre et al.(2008), Poler et al. (2008), Sari (2008a), Du et al. (2009), Danese (2011), Büyüközkan and Vardaloğlu (2012) }\end{array}$ \\
\hline Marketing actions & $\begin{array}{l}\text { Barratt and Oliveira (2001), Holmström et al. (2002), Larsen et al. (2003), Danese et al. (2004), Simatupang and Sridharan (2005), Caridi } \\
\text { et al. (2006), Danese (2006b), Thron et al. (2006), Chang et al. (2007), Chen et al. (2007), Thron et al. (2007), D'Aubeterre et al. (2008), } \\
\text { Ghosh and Fedorowicz (2008), Sari (2008b), Büyüközkan et al. (2009), Du et al.(2009), Baumann (2010), Shu et al.(2010), Danese } \\
\text { (2011), Audy et al. (2012), Ramanathan and Gunasekaran (2014) }\end{array}$ \\
\hline \multicolumn{2}{|l|}{ Inventory/Production } \\
\hline Inventory policy & $\begin{array}{l}\text { Caridi et al. (2006), Danese (2006b), Chang et al. (2007), Chang and Wang (2008), D'Aubeterreet al.(2008), Du et al. (2009), Shu et al. } \\
\text { (2010) }\end{array}$ \\
\hline Inventorylevel & $\begin{array}{l}\text { Stank et al. (1999), Barratt and Oliveira (2001), Holmström et al. (2002), Larsen et al. (2003), Simatupang and Sridharan (2005), Caridi } \\
\text { et al. (2006), Danese (2006b), Thron et al. (2006), Attaran and Attaran (2007), Chang et al. (2007), Chen et al. (2007), Danese (2007), } \\
\text { Thron et al. (2007), D'Aubeterre et al. (2008), Ghosh and Fedorowicz (2008), Sari (2008a), Sari (2008b), Büyüközkan et al. (2009), Choi } \\
\text { and Sethi (2010), Danese (2011), Audy et al. (2012), Yao et al. (2013) }\end{array}$ \\
\hline Production capacity and data & Larsen et al. (2003), Caridi et al. (2006), Chen et al. (2007), Danese (2007), Audy et al. (2012), Yao et al. (2013) \\
\hline Functional plans & $\begin{array}{l}\text { Fliedner (2003), Larsen et al. (2003),Simatupang and Sridharan (2005), Caridi et al. (2006), Thron et al. (2006), Attaran and Attaran } \\
\text { (2007), Du et al. (2009), Ramanathan and Gunasekaran (2014) }\end{array}$ \\
\hline
\end{tabular}


Table 5 - Classification of inputs to the CPFR process

\begin{tabular}{ll}
\hline Type of Inputs & References \\
\hline $\begin{array}{l}\text { Source/Delivery } \\
\text { Service level targets }\end{array}$ & $\begin{array}{l}\text { Fliedner (2003), Danese et al. (2004), Simatupang and Sridharan (2005), Danese (2006b), Attaran and Attaran (2007), Büyüközkan et } \\
\text { al.(2009) }\end{array}$ \\
\hline Functional plans & $\begin{array}{l}\text { Larsen et al. (2003), Danese (2006b), Attaran and Attaran (2007), Chang et al. (2007), Danese (2007), Småros (2007), Thron et al. } \\
\text { (2007), D'Aubeterre et al.(2008), Ghosh and Fedorowicz (2008), Büyüközkan et al. (2009), Du et al.(2009), Baumann (2010), Danese } \\
\text { (2011), Audy et al. (2012), Ramanathan and Gunasekaran (2014) }\end{array}$ \\
\hline Shipments & Simatupang and Sridharan (2005), Chang and Wang (2008), D'Aubeterre et al. (2008), Ghosh and Fedorowicz (2008), Du et al. (2009) \\
\hline Delivery lead time & Larsen et al. (2003), Audy et al. (2012) \\
\hline Transportation status & Danese (2006b) \\
\hline Finance & Caridi et al. (2006) \\
\hline Grormation and financial flows & Simatupang and Sridharan (2005) \\
\hline
\end{tabular}




\subsection{4. \\ Structure and processes}

Structure and processes vary according to the CPFR model adopted and can be subdivided into meetings and collaboration, organisation, ICT and metrics. Meetings are the "primary vehicle used in the organisation to facilitate mutual adjustment", according to Mintzberg, who defines it as a "liaison device" (Mintzberg, 1979; Danese, 2006b). Participants collaborating inside the firm and among firms vary according to the level of maturity of the CPFR process and the SC network (Larsen et al., 2003; Danese, 2011). Participant companies can be a dyad in a one-to-one relationship, or a one-to-many or many-to-one networks (Danese, 2007). In addition, CPFR can include both upstream and downstream partners of the focal company (e.g., supplier-manufacturer-retailer network). The large majority of the papers describe CPFR in the downstream network. One reason for this is that in the upstream network companies sell and market different products, so the collaboration is limited to order forecast, as it is infeasible for suppliers to participate in joint promotional and sales forecast plans (Danese, 2006a). For Danese (2004, 2006b), the depth of the collaboration defines the type of "liaison devices", with liaison positions (a liaison agent without managerial authority) corresponding to communication-type of CPFR, task forces and standing committees/institutionalised meetings corresponding to limited collaboration and integrating managers with formal authority being empowered under full collaboration.

Several authors emphasise the need for internal coordination as well (Stank et al., 1999, Barratt and Oliveira, 2001, Fliedner, 2003, Cassivi, 2006, Småros, 2007, Büyükozkän et al., 2009, Büyükozkän and Vardaloğlu, 2012). Chang and Wang (2008) describe a bottom up CPFR for a paper industry in Taiwan, with POS data inputs in sales database by retailers, aggregated in product families by the salespersons and reported to the regional manager, who produces a regional order forecast; order forecasts are aggregated in the head office for all regions and generate the whole order. Büyükozkän et al. (2009) and Büyükozkän and Vardaloğlu (2012) quote the need of internal collaboration among departments (purchasing, manufacturing, logistics, marketing, $R \& D$ ) in the CPFR process. 
The relationships in CPFR guidelines are governed by a front-end agreement on supplying and ordering, with shared risks and profits (VICS, 1998, 2004, 2010, ECR Europe, 2001, Yuan et al., 2010). In addition to commit resources (Büyükozkän et al., 2009), several authors emphasise the need to reduce gaming and to develop trust and confidence among partners (Barratt and Oliveira, 2001, Fliedner, 2003, Larsen et al., 2003, Attaran, 2004, Cassivi, 2006, Attaran and Attaran, 2007, Chen et al., 2007, Chang and Wang, 2008, Ghosh and Fedorowicz, 2008, Buyukozkan et al., 2009, Choi and Sethi, 2010, Yuan et al., 2010, Buyukozkan and Vardaloğlu, 2012); which is viewed by most as a long term endeavor (Larsen et al., 2003, Danese, 2004, 2007, Caridi et al., 2006, Cassivi, 2006, Attaran and Attaran, 2007, Büyükozkän et al., 2009, Büyükozkän and Vardaloğlu, 2012).

According to Larsen et al. (2003), CPFR can be subdivided into basic, developing and advanced. In basic CPFR only few partners and processes are involved (e.g., exchange of stock level data for order planning) and it is driven by the need to lower transactional costs. In developed CPFR there is increased integration in several areas driven by the desire to make delivery faster and more precise, enhancing service level and customers responsiveness from a network theoretical view point. Under advanced CPFR, planning and decision making are synchronised including production planning, promotions, marketing and new products launching, in a relationship that is RBV and aiming at long term mutual learning. Companies enter basic CPFR-like agreements due to its low transactional costs, move to a network perspective under developed CPFR and into a mutually beneficial long term RBV exchange under advanced CPFR (Larsen et al., 2003, Hvolny and Trienekens, 2010, Ramanathan and Gunasekaran, 2014). Some authors advocate that CPFR collaboration should start with transactional information sharing and evolve to more mature models gradually (Barratt and Oliveira, 2001, ECR Europe, 2001, Larsen et al., 2003, Seifert, 2003, Danese, 2007). From a contingency theory view point, Danese (2006b) proposes that CPFR matures as a function of the depth of collaboration and the number of units involved in the process and would not result from experience gained through time alone, that would be independent of corporate strategies and context.

Meeting regularity varies from one network to another: joint business plans every semester in Network B and every year in Network C (Danese et al., 2004); 
yearly promotional plan reviewed every three months in Network $\mathrm{H}$ and yearly joint promotional plan reviewed within a fixed schedule every week - sales forecasts on Fridays, exceptions management on Mondays, order forecasts on Tuesdays and order forecasts exception management on Wednesdays in Network I (Danese, 2011); bi-weekly joint replenishment and weekly demand forecasts on a rolling basis (D'Aubeterre et al., 2008); quarterly meetings (Simatupang and Sridharan, 2005); daily, weekly and monthly meetings (Danese, 2006b); monthly (Baumann, 2010); three times a year (Holmström et al., 2002). For Smith et al. (2010), CPFR meetings regularity should parallel S\&OP, with routine communication meetings and conference calls to solve exceptions to demand and order forecasts.

Organisational readiness for collaboration is a key factor for CPFR to succeed and refers to having adequate technological capacity, educated employees, financial sufficiency and willingness and organisational culture to collaborate with trading partners (Larsen et al., 2003, Büyükozkän et al., 2009, Du et al., 2009, Burnette, 2010, Büyükozkän and Vardaloğlu, 2012). Lack of internal integration (Småros, 2007), of collaborative forecasting training (Attaran, 2007, Chen et al., 2007), and of a flexible organisational structure (Attaran, 2007) are quoted as organisational impediments to a successful CPFR implementation.

Teams involved in CPFR can vary significantly from one case to the other (Danese, 2006b). Cross functional teams within the participating companies are extensively treated in the S\&OP literature (Thomé et al., 2012a), which is embraced by VICS 2010 guidelines (VICS, 2010, Baumann, 2010, Smith et al., 2010). "Liaison devices" (Danese, 2006b) among companies are described under Meetings, above. The teams participating in CPFR meetings are cross functional (Büyükozkän and Vardaloğlu, 2012). Simatupang and Sridharan (2005) refer to "interface teams" of merchandising, purchasing and distribution at the retailer and a supplier team composed of sales, planning/forecast and logistics personnel. Baumann (2010) refers to a collaborative demand team composed of staff from sales, marketing, product/brand management, demand planning. Stank et al. (1999) clearly refer to the need of internal cross functional work and the production of the "single number forecast" agreed upon by all functional areas of a company, before it engages in a fruitful collaboration in the SC. Larsen et al. (2003) state that the organisation involved in a CPFR project must be market- 
oriented rather than the traditional functional approach based on a productionoriented vision. Several authors also quote the importance of top management support (Attaran and Attaran, 2007, Chen et al., 2007, Smith, 2010, Büyükozkän and Vardaloğlu, 2012, Ramanathan, 2014). In 2010, VICS presents guidelines for a maturity model for collaboration linking CPFR to the internal collaboration provided by $\mathrm{S} \& \mathrm{OP}$, emphasising the role of ICT in the joint CPFR/S\&OP process (Baumann, 2010, Smith et al., 2010, VICS, 2010).

There is no consensus about the required steps and the agenda for CPFR, despite the fact that most of the discussion on the subject is based on the original VICS (1998) model, as discussed previously in sub-section 3.3. The basic agenda for CPFR consists in establishing the collaborative goals at the front-end agreement and expanding gradually in terms of complexity and scope (ECR Europe, 2001, Larsen et al., 2003, Seifert, 2003, Danese, 2011).

Appropriate ICT is necessary in all steps of the process. ECR Europe (2002) emphasise that simple technologies can be used such as fax, spreadsheets of sales, emails on orders and forecast, as well as more complex ICT tools as EDI, web portals, synchronised joint forecasting and simulation. Danese (2006b) posits that ICT may vary based on the level of complexity of CPFR (depth of collaboration), the "liaison devices" used for collaboration and the number of partners involved in the network. It evolves from communication exchange with electronic data exchange and data integration to the addition of automated planning systems under limited collaboration of joint planning to internet-based software solutions under full synchronised collaboration. Costs increase with increased levels of ICT sophistication. Caridi et al. $(2005,2006)$ propose two CPFR models with autonomous agents with different levels of "intelligence" to improve the results form CPFR. Thron et al. (2006) and Ramanathan (2014) argue that simulation analysis can be conducted prior to implementation, avoiding the pitfalls and costs of unsuccessful CPFR projects.

The most common metrics encountered in the CPFR literature are depicted in Table 6, regrouped in the categories of financial (profitability and costs), market-related (forecast accuracy, lost sales, sales growth, order fulfillment and service level) and operational metrics (inventory management, material flow and production). Among the later, delivery/transportation, perfect deliveries/supplies prevail. Financial and operational metrics would be more related to the CPFR goal 
of efficiency and market-related metrics would be more related to the goal of responsiveness. The same classification will be used to describe outcomes and results from the research synthesis framework. Appenix II also presents the CPFR metrics. 
Table 6 - CPFR metrics

\begin{tabular}{|c|c|}
\hline Type of metrics & References \\
\hline \multicolumn{2}{|l|}{ Financial } \\
\hline Profitability & Simatupang and Sridharan (2005), Du et al. (2009) \\
\hline Costs & Caridi et al. (2005, 2006), Chen et al. (2007), Sari (2008b) \\
\hline \multicolumn{2}{|l|}{ Market-related } \\
\hline Forecast accuracy & Holmström et al. (2002), Simatupang and Sridharan (2005), Chang and Wang (2008), Du et al. (2009), Yao et al. (2013) \\
\hline Sales & Caridi et al. (2006), Du et al. (2009) \\
\hline Order fulfillment & Simatupang and Sridharan (2005), Thron et al. (2006), Chen et al. (2007), Thron et al. (2007), Du et al.(2009), Yuan et al. (2010) \\
\hline Service level & Holmström et al. (2002), Thron et al. (2006), Thron et al. (2007), Chen et al. (2007), Sari (2008b), Yuan et al. (2010) \\
\hline \multicolumn{2}{|l|}{ Operational } \\
\hline Inventory management & Caridi et al. (2005, 2006), Du et al. (2009), Simatupang and Sridharan (2005), Thron et al. (2007), Yuan et al. (2010), Yao et al. (2013) \\
\hline $\begin{array}{l}\text { Material flow } \\
\text { (delivery/transportation) }\end{array}$ & Thron et al. (2006), Thron et al. (2007) \\
\hline Production & Thron et al. (2006) \\
\hline
\end{tabular}




\subsection{5.}

\section{Outcomes and results}

The outcomes from CPFR are described as collaborative plans that synchronise forecasts, based on which the production and replenishment processes take place (Larsen et al., 2003). The CPFR process is based in SC partners' joint decisions and the dynamics of the replenishment process (Barratt and Oliveira, 2001). Sales, promotions, production, purchasing and product development are jointly planned (Larsen et al., 2003, Attaran, 2004, Attaran and Attaran, 2007, Danese, 2007, Sari, 2008b, Yao et al., 2013, Ramanathan and Gunasekaran, 2014). A single demand projection is created, so the companies have a unique and mutually agreed forecast (Larsen et al., 2003, Ireland, 2005, Danese, 2006b, 2007, Chang et al, 2007, Chen et al, 2007, Yao et al., 2013, Ramanathan, 2014). Based on this forecast the production and the activities to deliver products in response to market demand are synchronised and collaborative inventory replenishment is developed (Sherman, 1998, Larsen et al., 2003, Danese, 2007, Yao et al., 2013). These outcomes are the means to achieve the results presented in Table 7. The results are regrouped in three categories (financial, market related and operational) and subcategories, along with the number of time each result indicator was quoted within a given subcategory.

Results related to the goal of SC responsiveness (144 quotes) outnumber results reported for efficiency in the SC (67 for finance and 70 for operations). Among the market-related indicators, the most commonly encountered results are improved forecast accuracy, sales growth, improved customer service/service level, product availability and improved inventory. Among the financial indicators, reduction in SC costs and inventory cost reduction are the mostly quoted ones. The operational indicators reported most often are reduced inventory and obsolescence. Appenix III also presents the results of the CPFR process. 
Table 7 - Results of the CPFR process

\begin{tabular}{|c|c|c|}
\hline Results & \# of quotes & References \\
\hline \multicolumn{3}{|l|}{ Financial } \\
\hline Revenues & 13 & $\begin{array}{l}\text { Sherman (1998), McCarthy and Goilicic (2002), Esper and Williams (2003), Ireland (2005), Attaran and Attaran (2007), Chang et } \\
\text { al. (2007), D'Aubeterre et al. (2008), Du et al. (2009) }\end{array}$ \\
\hline Profitability & 10 & $\begin{array}{l}\text { Stank et al. (1999), Fliedner (2003), Attaran and Attaran (2007), Chang et al. (2007), Chen et al. (2007), Du et al. (2009), Smith et } \\
\text { al. (2010), Ramanathan and Gunasekaran (2014) }\end{array}$ \\
\hline Costs & 44 & $\begin{array}{l}\text { Sherman (1998), Stank et al. (1999), Barratt and Oliveira (2001), Esper and Williams (2003), Fliedner (2003), Larsen et al. (2003), } \\
\text { Attaran (2004), Ireland (2005), Simatupang and Sridharan (2005), Caridi et al. (2006), Cassivi (2006), Danese (2006b), Attaran } \\
\text { and Attaran (2007), Chen et al. (2007), Danese (2007), Chang and Wang (2008), D'Aubeterre et al. (2008), Ghosh and } \\
\text { Fedorowicz (2008), Poler et al. (2008), Büyüközkan et al. (2009), Du et al. (2009), Burnette (2010), Lapide (2010), Smith et al. } \\
\text { (2010), Ramanathan and Gunasekaran (2014) }\end{array}$ \\
\hline \multicolumn{3}{|l|}{ Market-related } \\
\hline Time to market & 22 & $\begin{array}{l}\text { Fliedner (2003), Attaran (2004), Ireland (2005), Simatupang and Sridharan (2005), Danese (2006b), Attaran and Attaran (2007), } \\
\text { Chen et al. (2007), Danese (2007), Chang and Wang (2008), Burnette (2010), Hvolby and Trienekens (2010), Shu et al. (2010) }\end{array}$ \\
\hline Forecast accuracy & 20 & $\begin{array}{l}\text { Sherman (1998), Stank et al. (1999), Esper and Williams (2003), Fliedner (2003), Attaran (2004), Ireland (2005), Attaran and } \\
\text { Attaran (2007), Chang et al. (2007), Danese (2007), Småros (2007), Chang and Wang (2008), Du et al. (2009), Smith et al. (2010), } \\
\text { Büyüközkan and Vardaloğlu (2012), Ramanathan and Gunasekaran (2014) }\end{array}$ \\
\hline Sales & 32 & $\begin{array}{l}\text { Sherman (1998), Stank et al. (1999), Holmström et al. (2002), McCarthy and Goilicic (2002), Esper and Williams (2003), Fliedner } \\
\text { (2003), Larsen et al. (2003), Attaran (2004), Ireland (2005),Simatupang and Sridharan (2005), Caridi et al. (2005), Cassivi } \\
\text { (2006),Caridi et al. (2006), Danese (2006b), Attaran and Attaran (2007), Chang et al. (2007), Chen et al. (2007), Danese (2007), } \\
\text { Småros (2007), Poler et al. (2008), Du et al. (2009), Burnette (2010), Lapide (2010), Smith et al. (2010), Yuan et al. (2010), } \\
\text { Büyüközkan and Vardaloğlu (2012), Ramanathan and Gunasekaran (2014) }\end{array}$ \\
\hline Demand uncertainty & 5 & Stank et al. (1999), Fliedner (2003), Attaran and Attaran (2007), Chen et al. (2007) \\
\hline Order fulfillment & 18 & $\begin{array}{l}\text { Stank et al. (1999), Barratt and Oliveira (2001), Fliedner (2003), Attaran (2004), Simatupang and Sridharan (2005), Danese } \\
\text { (2006b), Attaran and Attaran (2007), Chang et al. (2007), Danese (2007), Ghosh and Fedorowicz (2008), Sari (2008b) }\end{array}$ \\
\hline Service level & 47 & $\begin{array}{l}\text { Stank et al. (1999), Barratt and Oliveira (2001), Holmström et al. (2002), Esper and Williams (2003), Fliedner (2003), Larsen et al. } \\
\text { (2003), Attaran (2004), Simatupang and Sridharan (2005), Caridi et al. (2005, 2006), Cassivi (2006), Thron et al. (2006), Attaran } \\
\text { and Attaran (2007), Chang et al. (2007), Chen et al. (2007), Danese (2007), Smăros (2007), Chang and Wang (2008), Ghosh and } \\
\text { Fedorowicz (2008), Sari (2008b), Du et al. (2009), Burnette (2010), Lapide (2010), Smith et al. (2010), Yuan et al. (2010), } \\
\text { Büyüközkan and Vardaloğlu (2012) }\end{array}$ \\
\hline
\end{tabular}


Table 7 - Results of the CPFR proces

\begin{tabular}{|c|c|c|}
\hline Results & \# of quotes & References \\
\hline \multicolumn{3}{|l|}{ Operational } \\
\hline Inventory management & 44 & $\begin{array}{l}\text { Sherman (1998), Stank et al. (1999), Barratt and Oliveira (2001), Holmström et al. (2002), McCarthy and Goilicic (2002), Esper } \\
\text { and Williams (2003), Fliedner (2003), Larsen et al.(2003), Attaran (2004), Caridi et al. (2005), Simatupang and Sridharan (2005), } \\
\text { Thron et al. (2006), Chang et al. (2007), Chen et al. (2007), Danese (2007), Småros (2007), Ghosh and Fedorowicz (2008), Poler } \\
\text { et al. (2008), Sari (2008b), Du et al. (2009), Burnette (2010), Lapide (2010), Shu et al. (2010), Smith et al. (2010), Yuan et al. } \\
\text { (2010), Büyüközkan and Vardaloğlu (2012), Ramanathan and Gunasekaran (2014) }\end{array}$ \\
\hline Material management & 7 & Stank et al. (1999), Barratt and Oliveira (2001), Fliedner (2003), Du et al. (2009) \\
\hline $\begin{array}{l}\text { Material flow } \\
\text { (delivery/transportation) }\end{array}$ & 15 & $\begin{array}{l}\text { Stank et al. (1999), Barratt and Oliveira (2001), Attaran (2004), Simatupang and Sridharan (2005), Thron et al. (2006), Attaran } \\
\text { and Attaran (2007), Chen et al. (2007), Smith et al. (2010) }\end{array}$ \\
\hline Production & 4 & Stank et al. (1999), Fliedner (2003), Thron et al. (2006) \\
\hline
\end{tabular}


During the review process, just three confirmatory studies submitted CPFR processes to the test of hypothesis related to its impact on SC performance and met with mixed results. Stank et al. (1999) analyse a sample of 98 USA manufacturing and retailing firms from the 1998 roster of the Council of Logistics Management. Univariate positive associations are found between high levels of implementation of CPFR and: (i) operational changes; and (ii) enhanced information capabilities. But the authors find a "very weak" association between CPFR and the effectiveness of operational results in the SC. Yao et al. (2013) submit CPFR to test with a transactional database of nine products of a phone company and a major retailer in the USA, concluding that CPFR learning curves and the sequencing of product launching impact upon forecast errors and inventory levels. Ramanathan and Gunasekaran (2014) apply structural equation modeling and confirmatory factor analysis to a sample of 150 companies (wholesalers, distributors, retailers and private customers) belonging to the network of a large textile industry in India. The authors find a positive impact of collaborative planning and collaborative execution on the success of collaboration and on future collaboration in the SC. Collaborative decision making exert a positive impact upon the success of collaboration, which in turn result in increased future collaboration. Collaborative planning and decision making also impact positively upon collaborative execution. The empirical results corroborate the hypothesis that CPFR is a long term endeavor as actual collaborative planning, execution and decision making impact positively upon the success of the collaboration, which is a driver for future collaboration and for collaborative execution. 


\section{5 \\ Conclusions and future research}

This dissertation provides a systematic review aimed to synthesise the highly dispersed literature on CPFR. To the best of our knowledge, this is the first study to do so. Six hundred twenty-nine abstracts and 53 full-text papers were initially retrieved, and 47 were analysed for the final review. The review followed a systematic and objectively verifiable methodology of research synthesis, thereby enabling replication and objective back check on results.

Despite the growing volume of publications in the subject, the field is still recent and evolving, with a large majority of conceptual papers, case study research and simulations that are exploratory and aiming at understanding CPFR mechanisms and impact upon SC performance. Results from case studies provide promising theoretical generalisations. But case study research still lacks confirmation and generalisation to different industries. No systematic statistical inference and test of hypothesis were found but in two survey-based studies and one transactional database research.

A common and universally accepted definition of CPFR configurations was not found, but several variations of the 1998 and 2004 VICS models, with the exception of Fliedner (2003), were found. A summary definition was proposed based on the literature review that emphasised CPFR as being a cohesive bundle of management practices of joint planning and decision making aimed at bridging supply and demand, strategy and operations among SC partners with the aim of improving SC performance.

The main enablers observed in the literature were trust and ICT. Conversely, the lack thereof was the main barrier. However, as these enablers cannot succeed alone, the success of CPFR implementation depends on a host of contextual factors, such as demand elasticity and uncertainty, goals of the process, number of products, SC spatial complexity and the levels and scope of collaboration (Danese, 2011). 
Numerous terms exists in the CPFR literature that refer to the same basic concepts, such as steps, stages, tasks and activities. The terms vary from author to author and from model to model with respect to the same author (e.g., steps and tasks in the 1998 and 2004 VICS models). There is no consensus with respect to the use of the terms and no taxonomy regarding their use, thereby making research synthesis and meta-analysis difficult. It is also difficult to summarise the implementation steps for CPFR as there is no agreement about the number of steps or the order in which the steps should be implemented. However, the variants of the CPFR model are based on the same building principles as those of the basic VICS model, thereby encompassing the four foundations of collaboration, planning, forecast and replenishment. Furthermore, several authors agree that a given CPFR configuration is context-dependent and can present a variety of formats and that a given network can implement several simultaneously or limit the collaboration to some rather than all of the steps of the basic VICS model (ECR Europe, 2001, Larsen et al., 2003, VICS, 2004, Danese, 2011).

Maturity model for CPFR can assist in classifying collaboration under different SC configurations. Contrary to other areas such as information systems and S\&OP (Thomé et al., 2012a), CPFR maturity model is on its infancy with just one model. There is room to expand upon the original model with the CPFR experiences and information gained in the past ten years since its inception. Being the sole model proposed in the literature, it is particularly prone to cumulative theory building (Rousseau, 2006).

Contingency theory in the area of SCC is also a fertile field for research (Sousa and Voss, 2008). There is a need to validate Danese's exploratory, theorybuilding hypothesis with different industries and countries, as well as with larger samples (Danese et al., 2004, Danese, 2006b, 2007, 2011). All available contingency propositions are based on case study qualitative research, which leads to theoretical generalisations but not to statistical inferences and validation (Yin, 1984). Three suggestions are made to improve upon operation management practice contingency research in CPFR: (i) to identify and expand upon existing contextual variables and contingency models; (ii) to validate and verify the generalisation of existing models; (iii) to apply survey research techniques for statistical validity and representativeness. 
Several authors noted that SC configurations other than CPFR, such as VMI and $\mathrm{CR}$, can provide the best results at a lower cost under specific circumstances (e.g., McCarthy and Golicic, 2002, Sari, 2008a, 2008b, Yuan et al., 2010). As the choice of the most adequate SCC initiative is not an easy task, it should embrace issues such as performance trade-offs (Sari, 2008a, 2008b), the power of retailersupplier relationships (Tyan and Wee, 2003) knowledge and technology levels as well as trust in trading partners (Chen et al., 2010, Yuan et al., 2010). Moreover, CPFR can be implemented successfully when linked to other SCC initiatives, such as VMI, JMI or CR (Danese et al., 2004, Thron et al., 2006, 2007) or with others business practices, such as S\&OP and CTM (Du et al., 2009, Baumann, 2010, Smith et al., 2010, VICS, 2010).

The synthesis framework was based on an early integration model enriched in-light of CPFR theories emanated from maturity models, RBV, RDT and contingency theory. VICS' models are criticised by proponents of maturity models in CPFR, arguing that at different development stages CPFR configurations would differ (Larsen et al., 2003). The maturity model is a valid explanation to the fact that different CPFR configurations might exist but one of its drawbacks is that it falls short in explaining the influence of the environment and context. Also, it might mislead to the expectation that with time all networks converge to the advanced stage of CPFR (Danese, 2011). A different and complementary theoretical perspective is adopted by Ramanathan and Gunasekaran (2014): the RBV and RDT theories. The RBV states that firms engage inimitable and unique resources in order to gain competitive advantage (Barney, 1991). It might explain why companies prefer to limit collaboration even when their relationships are mature and the context is favorable to full collaboration. RDT supports the dependency of SC members; in particular, SC partners seeking high performance will tend to depend on each other and to collaborate for long term results (Ramanathan and Gunasekaran, 2014). The literature review also led to important avenues for future research. For example, the lack of consensus regarding terms and steps for CPFR can lead to the development of future taxonomies. As there were relatively few articles based on case study and survey research, hypothesis verification regarding CPFR impact on performance was challenging. Thus, this is a new field worthy of exploration. Four suggestions are offered to strengthen CPFR research. First, survey-based 
scales to measure the scope and breadth of CPFR configurations are yet to be developed and tested. The research propositions from case study research on CPFR are good candidates for replication, and verification of their generalisation to larger samples and different industries is necessary. Second, the contextual factors explaining different CPFR configurations should be further explored. Third, important research areas emerge from the limitations of maturity models and of contingency theory. While the first can help explaining how SCC evolves, the later inform under which conditions it might happen. But none of them deals with the fact that companies may voluntarily choose not to collaborate, even when their relationships are mature and the context is favorable. RBV and RDT come handy under such circumstances (Ramanathan and Gunasekaran, 2014). Other theories should also be explored and applied to the understanding of SCC. Examples are the external/institutional limitations emanated from governments, corporate policies, trade unions, etc., as informed by institutional theory (Sousa and Voss, 2008, Danese, 2011). Fourth, there is a need to understand better the integration of CPFR with other SCC initiatives and to understand better how companies can choose the more adequate SCC initiative for its SC. Of particular interest is the investigation of the paradigmatic integration of CPFR with other SCCs, such as VMI and CR, and with internal management practices, such as S\&OP.

The results provide some guidance for practitioners. They can benefit from the use of simulation models to mimic SC performance under different collaboration schemes at a lower cost than trials and errors in real-life experiments in SCC. Important caveats to defining the scope of collaboration are also provided, such as the number of partners, nature of products, and spatial complexity of the network, as they can guide companies in selecting the aim and contractual arrangements for SCC. The need to carefully outweigh the cost benefit of investments in ICT and the high relevance of the "soft" aspects related to trust and power relationship are important areas to be scrutinised by practitioners facing specific SC configurations. Practitioners can make use of very detailed implementation guidelines for CPFR (VICS, 1998, 2004, 2010, ECR Europe, 2001). But critical reviews of implementation steps are also of immediate use. Maturity models can be used as a check list for implementation. CPFR maturity model and contingency research demonstrates that under certain circumstances, 
basic collaboration might fit the needs of SC partners at a lower cost. Furthermore, the investment costs for the collaboration, in particular for ICT and organisational changes should be carefully outweighed against the expected benefits (Stank, 1999, Danese, 2011). Another important finding from CPFR research of relevance to management lies in the distinction between ICT and organisational changes. It is cautioned that misled and expensive investments in ICT would not result in the absence of the required organisational changes related to a culture of collaboration, trust and team work within the firm and between firms in the SC (Danese, 2006b, 2007, 2011, VICS, 2010, Baumann, 2010, Smith et al., 2010). The contingency approach to CPFR demonstrates that there is not such a general rule as a CPFR model with specific and rigid steps that would fit all companies, sectors and countries, regardless of context and environments. 


\section{References}

Attaran, M. Nurturing the supply chain. Industrial Management, v. 46, n. 5, p. 16-20. 2004.

Attaran, M.; Attaran, S. Collaborative supply chain management: the most promising practice for building efficient and sustainable supply chains. Business Process Management Journal, v. 13, n. 3, p. 390-404. 2007

Audy, J.-F.; Lehoux, N.; D’Amours, S.; Rönnqvist, M. A framework for an efficient implementation of logistics collaborations. International Transactions in Operational Research, v. 19, n. 5, p. 633-657. 2012

Barney, J.B. Firm resources and sustained competitive advantage. Journal of Management, v. 17, n. 1, p. 99-120. 1991.

Barratt, M.; Oliveira, A. Exploring the experiences of collaborative planning initiatives. International Journal of Physical Distribution \& Logistics Management, v. 31, n. 4, p. 266-289. 2001.

Baumann, F. The shelf-connected supply chain: strategically linking CPFR with S\&OP at the executive level. Journal of Business Forecasting, v. 29, n. 4, p. 2128. 2010.

Burgess, K.; Singh, P.J.; Koroglu, R. Supply chain management: a structured literature review and implications for future research. International Journal of Operations \& Production Management, v. 26, n. 7, p. 703-729. 2006.

Burnette, R. CPFR: fact, fiction, or fantasy? Journal of Business Forecasting, v. 29, n. 4, p. 32-35. 2010.

Büyüközkan, G.; Feyzioğlu, O.; Vardaloğlu, Z. Analyzing CPFR supporting factors with fuzzy cognitive map approach. World Academy of Science, v. 31, p. 412-417. 2009.

Büyüközkan, G.; Vardaloğlu, Z. Analyzing of CPFR success factors using fuzzy cognitive maps in retail industry. Expert Systems with Applications, v. 39, n. 12, p. 10438-10455. 2012.

Caridi, M.; Cigolini, R.; De Marco, D. Improving supply-chain collaboration by linking intelligent agents to CPFR. International Journal of Production Research, v. 43, n. 20, p. 4191-4218. 2005. 
Caridi, M.; Cigolini, R.; Marco, D. Linking autonomous agents to CPFR to improve SCM. Journal of Enterprise Information Management, v. 19, n. 5, p. 465-482. 2006.

Cassivi, L. Collaboration planning in a supply chain. Supply Chain Management: An International Journal, v. 11, n. 3, p. 249-258. 2006.

Chang, K.K.; Wang, F.K. Applying six sigma methodology to collaborative forecasting. The International Journal of Advanced Manufacturing Technology, v. 39, n. 9-10, p. 1033-1044. 2008.

Chang, T.-H.; Fu, H.-P.; Lee, W.-I.; Lin, Y.; Hsueh, H.-C. A study of an augmented CPFR model for the 3C retail industry. Supply Chain Management: An International Journal, v. 12, n. 3, p. 200-209. 2007.

Chen, M.-C.; Yang, T.; Li, H.-C. Evaluating the supply chain performance of ITbased inter-enterprise collaboration. Information \& Management, v. 44, n. 6, p. 524-534. 2007.

Choi, T.-M.; Sethi, S. Innovative quick response programs: a review. International Journal of Production Economics, v. 127, n. 1, p. 1-12. 2010.

Cooper, H. (2010). Research synthesis and meta-analysis: A step-by-step approach, California: Sage Publications, 2010. 280 p.

D’Aubeterre, F.; Singh, R.; Iyer, L. A semantic approach to secure collaborative inter-organizational ebusiness processes (SSCIOBP). Journal of the Association for Information Systems, v. 9, n. 3-4, p. 231-266. 2008.

Danese, P. How contextual factors shape CPFR collaborations: A theoretical framework. Supply Chain Forum, an International Journal, v. 7, n. 2, p. 1626. 2006 a.

Danese, P. Collaboration forms, information and communication technologies, and coordination mechanisms in CPFR. International Journal of Production Research, v. 44, n. 6, p. 3207-3226. 2006b.

Danese, P. Designing CPFR collaborations: insights from seven case studies. International Journal of Operations \& Production Management, v. 27, n. 2, p. 181-204. 2007.

Danese, P. Towards a contingency theory of collaborative planning initiatives in supply networks. International Journal of Production Research, v. 49, n. 4, p. 1081-1103. 2011.

Danese, P.; Romano, P.; Vinelli, A. Managing business processes across supply networks: the role of coordination mechanisms. Journal of Purchasing and Supply Management, v. 10, n. 4-5, p. 165-177. 2004. 
Derrouiche, R.; Neubert, G.; Bouras, A. Supply chain management: a framework to characterize the collaborative strategies. International Journal of Computer Integrated Manufacturing, v. 21, n. 4, p. 426-439. 2008.

Du, X.F.; Leung, S.C.H.; Zhang, J.L.; Lai, K.K. Procurement of agricultural products using the CPFR approach. Supply Chain Management: An International Journal, v. 14, n. 4, p. 253-258. 2009.

ECR, Europe. A Guide to CPFR Implementation (ECR Europe facilitated by Accenture), Brussels:2001. 105 p.

ECR, Europe, European CPFR insights, (ECR Europe facilitated by Accenture), Brussels:2002. 89 págs.

Eisenhardt, K.M. Building theories from case study research. Academy of Management Review, v. 14, n. 4, p. 532-550. 1989.

Esper, T.L.; Williams, L.R. The value of collaborative transportation management (CTM): its relationship to CPFR and information technology. Transportation Journal, v. 42, n. 4, p. 55-65. 2003.

Fliedner, G. CPFR: an emerging supply chain tool. Industrial Management \& Data Systems, v. 103, n. 1, p. 14-21. 2003.

Flynn, B.; Sakakibara, S.; Schroeder, R.G.; Bates, K.A.; Flynn, E.J. Empirical research methods in operations management. Journal of Operations Management, v. 9, n. 2, p. 250-284. 1990.

Ghosh, A.; Fedorowicz, J. The role of trust in supply chain governance. Business Process Management Journal, v. 14, n. 4, p. 453-470. 2008.

Holmström, J.; Främling, K.; Kaipia, R.; Saranen, J. Collaborative planning forecasting and replenishment: new solutions needed for mass collaboration. Supply Chain Management: An International Journal, v. 7, n. 3, p. 136-145. 2002.

Holweg, M.; Disney, S.; Holmström, J.; Småros, J. Supply chain collaboration: making sense of the strategy continuum. European Management Journal, v. 23, n. 2, p. 170-181. 2005.

Hopayian, K. The need for caution in interpreting high quality systematic reviews. Education and debate, v. 323, p. 681-684. 2001.

Hvolby, H.-H.; Trienekens, J.H. Challenges in business systems integration. Computers in Industry, v. 61, n. 9, p. 808-812. 2010.

Ireland, R. ABC of collaborative planning forecasting and replenishment. The Journal of Business Forecasting, v. 24, n. 2, p. 3-10. 2005. 
Kothari, C.R. Research methodology: methods \& techniques. Second edition. Delhi: New Age Publishers, 2004. 403p.

Kumar, G.; Banerjee, R.H. Collaboration in supply chain: An assessment of hierarchical model using partial least squares (PLS). International Journal of Productivity and Performance Management, v. 61, n. 8, p. 897-918. 2012.

Lapide, L. A history of CPFR. Journal of Business Forecasting, v. 29, n. 4, p. 29-31. 2010.

Larsen, T.S.; Thernøe, C.; Andresen, C. Supply chain collaboration: theoretical perspectives and empirical evidence. International Journal of Physical Distribution \& Logistics Management, v. 33, n. 6, p. 531-549. 2003.

McCarthy, T.M.; Golicic, S.L. Implementing collaborative forecasting to improve supply chain performance. International Journal of Physical Distribution \& Logistics Management, v. 32, n. 6, p. 431-454. 2002.

Mintzberg, H. The Structuring of Organizations. New Jersey: Prentice-Hall, 1979. $512 \mathrm{p}$.

Pinsonneault, A.; Kraemer, K. L. Survey research methodology in management information systems: an assessment. 1993. Available in: < http://escholarship.org/uc/item/6cs4s5f0>. Consulted in: January 2014.

Poler, R.; Hernandez, J.E.; Mula, J.; Lario, F.C. Collaborative forecasting in networked manufacturing enterprises. Journal of Manufacturing Technology Management, v. 19, n. 4, p. 514-528. 2008.

Ramanathan, U. Performance of supply chain collaboration - A simulation study. Expert Systems with Applications, v. 41, n. 1, p. 210-220. 2014.

Ramanathan, U.; Gunasekaran, A. Supply chain collaboration: impact of success in long-term partnerships. International Journal of Production Economics, v. 147, n. Part B, p. 252-259. 2014.

Rousseau, D. Is there such a thing as "evidence based management"? Academy of Management Review, v. 31, n. 2, p. 256-269. 2006.

Rowley, J, Slack, F. Conducting a literature review. Management Research News, v. 27, n. 6, p. 31-39. 2004.

Sari, K. Inventory inaccuracy and performance of collaborative supply chain practices. Industrial Management \& Data Systems, v. 108, n. 4, p. 495-509. 2008a.

Sari, K. On the benefits of CPFR and VMI: a comparative simulation study. International Journal of Production Economics, v. 113, n. 2, p. 575-586. 2008b. 
Seifert, D. Collaborative Planning Forecasting and Replenishment: How to Create a Supply Chain Advantage. New York: AMACOM, 2003. 411p.

Seuring, S.; Müller, M. From a literature review to a conceptual framework for sustainable supply chain management. Journal of Cleaner Production, v. 16, p. 1699-1710. 2008.

Sherman, R.J. Collaborative planning, forecasting and replenishment (CPFR): realizing the promise of efficient consumer response through collaborative technology. Journal of Marketing Theory and Pratice, v. 6, n. 4, p. 6-9. 1998.

Shu, T.; Chen, S.; Xie, C.; Wang, S.; Lai, K.K. AVE-CPFR working chains on the basis of selection model of collaborative credit-granting guarantee approaches. International Journal of Information Technology \& Decision Making, v. 9, n. 2, p. 301-325. 2010.

Simatupang, T.M.; Sridharan, R. The Collaborative Supply Chain. The International Journal of Logistics Management, v. 13, n. 1, p. 15-30. 2002.

Simatupang, T.M.; Sridharan, R. Benchmarking supply chain collaboration: An empirical study. Benchmarking: An International Journal, v. 11, n. 5, p. 484 503. 2004.

Simatupang, T.M.; Sridharan, R. An integrative framework for supply chain collaboration. The International Journal of Logistics Management, v. 16, n. 2, p. 257-274. 2005.

Småros, J. Forecasting collaboration in the European grocery sector: observations from a case study. Journal of Operations Management, v. 25, n. 3, p. 702-716. 2007.

Smith, L.; Andraski, J.C.; Fawcett, S.E. Integrated business planning: a roadmap to linking S\&OP and CPFR. Journal of Business Forecasting, v. 29, n. 4, p. 413. 2010.

Sousa, R.S.; Voss, C.A. Contingency research in operations management practices. Journal of Operations Management, v. 26, n. 6, p. 697-713. 2008.

Stank, T.P.; Daugherty, P.J.; Autry, C.W. Collaborative planning: supporting automatic replenishment programs. Supply Chain Management: An International Journal, v. 4, n. 2, p. 75-85. 1999.

Thomé, A.M.T.; Scavarda, L.F.; Fernandez, N.S.; Scavarda, A.J. Sales and operations planning: A research synthesis. International Journal of Production Economics, v. 138, n. 1, p. 1-13. 2012a.

Thomé, A.M.T.; Scavarda, L.F.; Fernandez, N.S.; Scavarda, A.J. Sales and operations planning and the firm performance. International Journal of Productivity and Performance Management, v. 61, n. 4, p. 359-381. 2012b. 
Thron, T.; Nagy, G.; Wassan, N. The impact of various levels of collaborative engagement on global and individual supply chain performance. International Journal of Physical Distribution \& Logistics Management, v. 36, n. 8, p. 596620. 2006.

Thron, T.; Nagy, G.; Wassan, N. Evaluating alternative supply chain structures for perishable products. The International Journal of Logistics Management, v. 18, n. 3, p. 364-384. 2007.

Tyan, J.; Wee, H-M. Vendor management inventory: a survey of the Taiwanese grocery industry. Journal of Purchasing \& Supply Management, v. 9, n. 1, p. 11-18. 2003.

VICS. CPFR Guidelines. 1998. Available in: 〈http://www.cpfr.org>. Consulted in: February 2005.

VICS. CPFR an overview. 2004. Available in:〈http://www.gs1us.org > Consulted in: January 2013.

VICS. Linking CPFR and S\&OP: A roadmap to Integrated Business Planning. 2010. Available in: 〈http://www.gs1us.org>. Consulted in: January 2013.

Voss, C.; Tsikriktsis, N.; Frohlic, M. Case research in operations management. International Journal of Operations and Production Management, v. 22, n. 2, p.195-219. 2002.

Weintraub, I. The impact of alternative presses on scientific communication. The International Journal on Grey Literature, v. 1, n. 2, p. 54-59. 2000.

Yao, Y.; Kohli, R.; Sherer, S.A.; Cederlund, J. Learning curves in collaborative planning, forecasting, and replenishment (CPFR) information systems: An empirical analysis form a mobile phone manufacturer. Journal of Operations Management, v. 31, n. 6, p. 285-297. 2013.

Yin, R.K. Case Study Research: Design and methods. California: Sage Publications, 1984. 160p.

Yuan, X.; Shen, L.; Ashayeri, J. Dynamic simulation assessment of collaboration strategies to manage demand gap in high-tech product diffusion. Robotics and Computer-Integrated Manufacturing, v. 26, n. 6, p. 647-657. 2010. 


\section{Appendix I - Classification of inputs to the CPFR process}

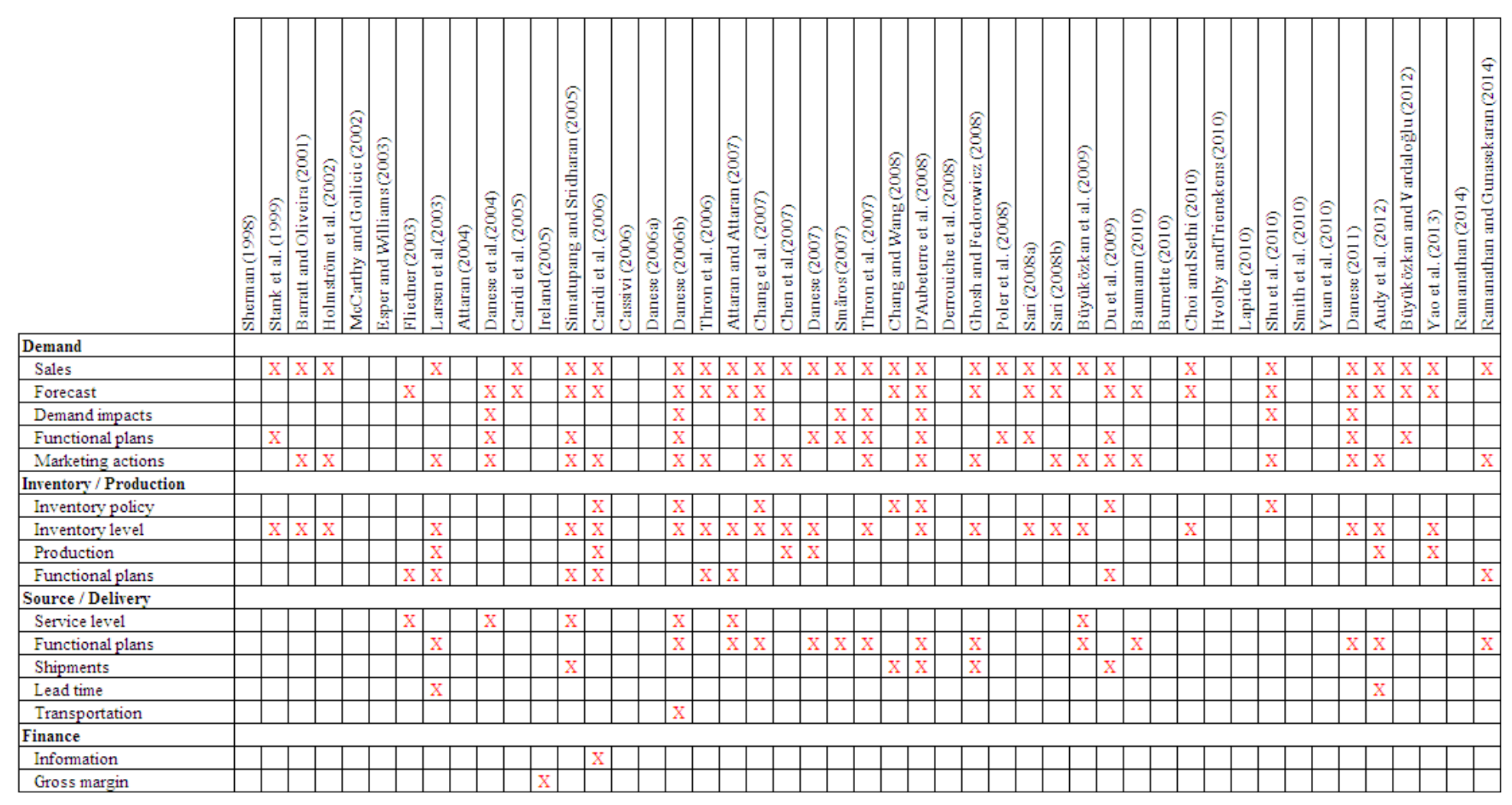




\section{Appendix II - CPFR metrics}

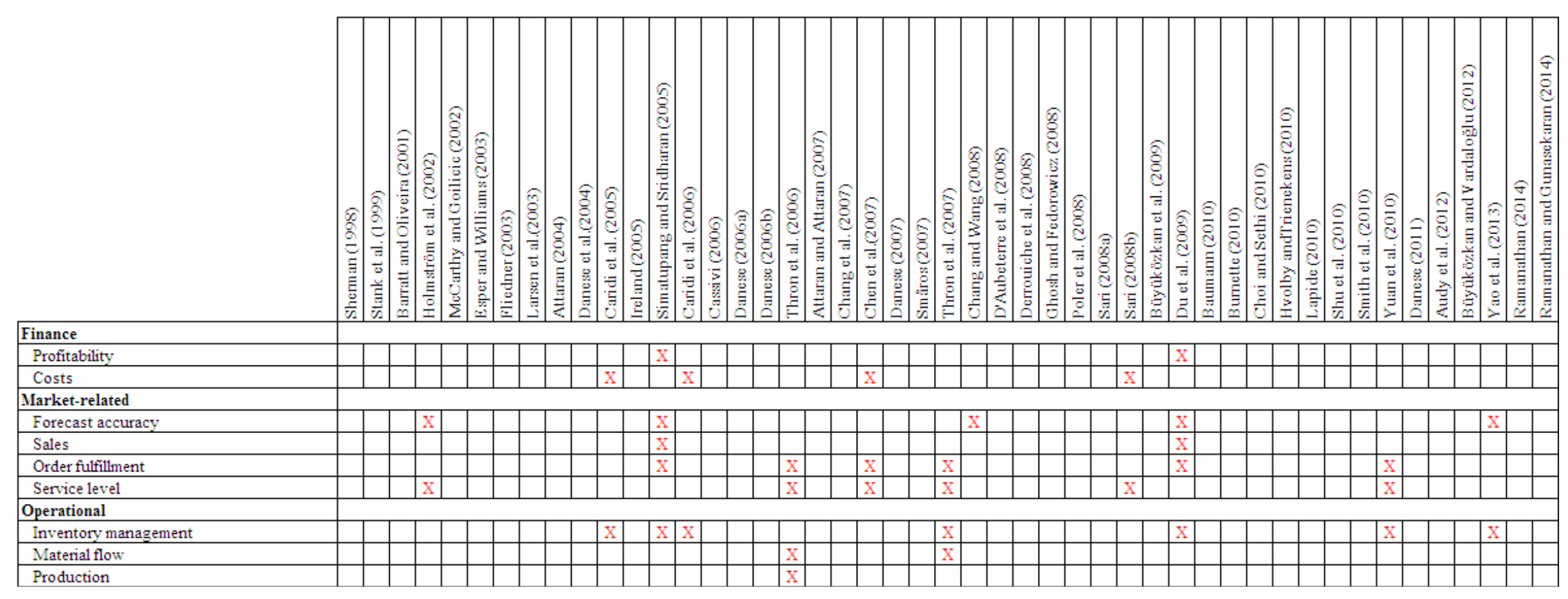




\section{Appendix III - Results of the CPFR process}

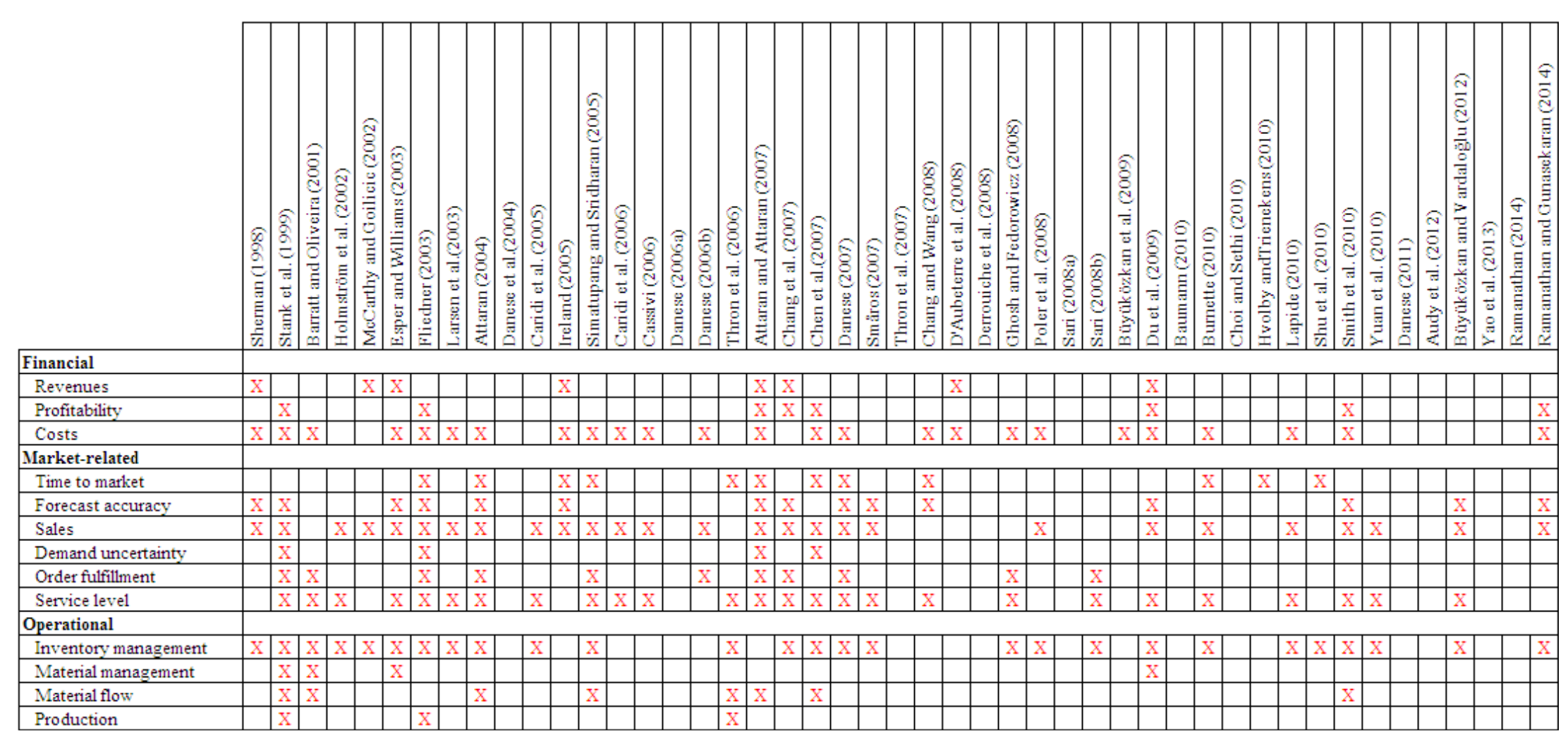

